\title{
Teatro e sociedade no Brasil colônia: a cena jesuítica do Auto de São Lourenço
}

\author{
Theatre and society in colonial Brazil: \\ the Jesuit scene of Auto de São Lourenço
}

Sérgio de Carvalho

Sérgio de Carvalho Professor do Departamento de Artes Cênicas e do PPGAC da ECA-USP

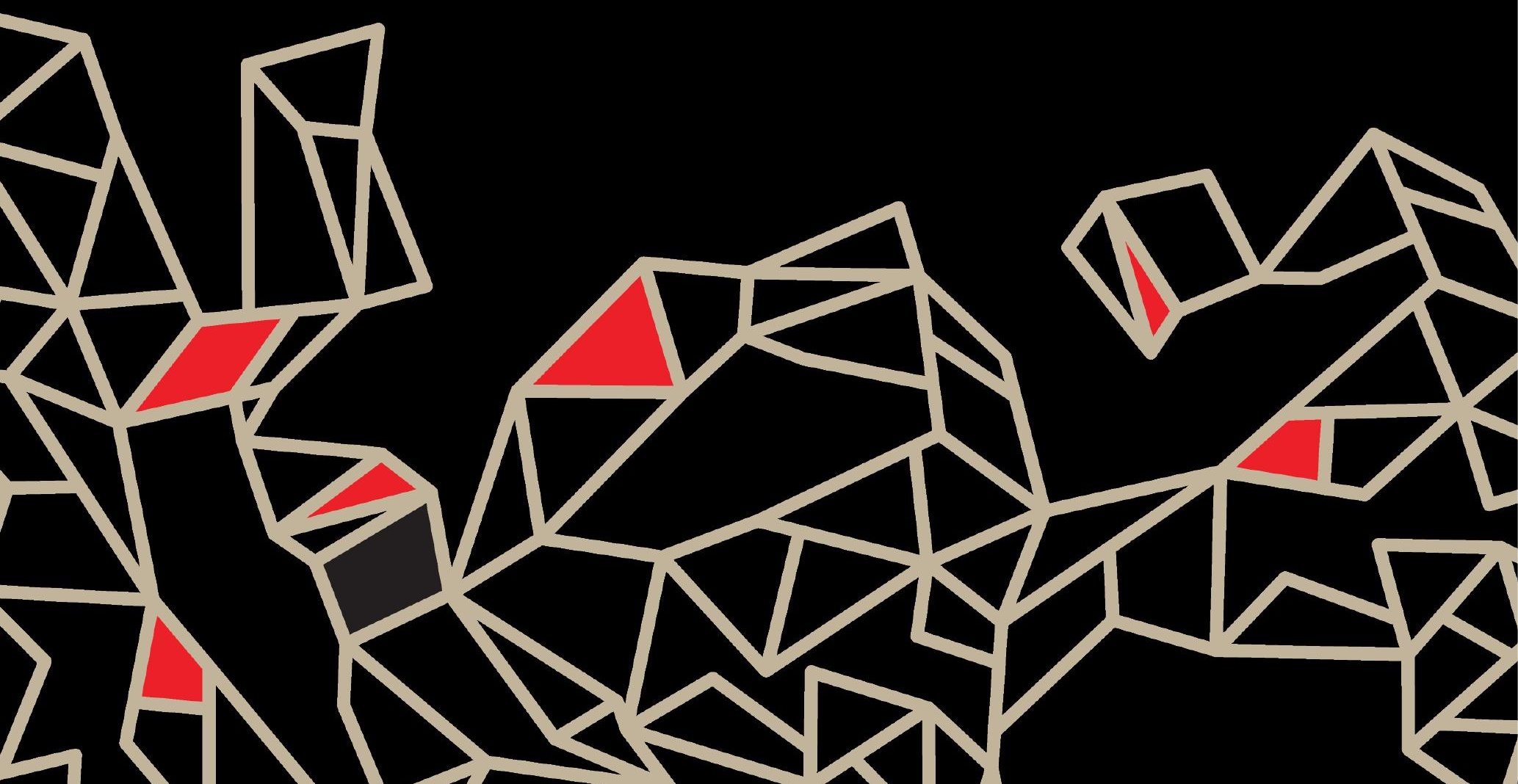




\section{Resumo}

O texto debate as principais dificuldades para o estudo do teatro no Brasil colônia, critica o conceito de teatro catequético e analisa o Auto de São Lourenço, de Padre Anchieta, a partir da conexão entre sua forma e o contexto histórico e político em que se produziu o aldeamento jesuítico.

Palavras-chave: Teatro jesuítico, Anchieta, Auto de São Lourenço, Teatralidade na colônia.

\section{Abstract}

This paper discusses the main difficulties on the study of theater in colonial Brazil, criticizes the concept of catechetical theater and analyzes Auto de São Lourenço, written by Padre Anchieta, from the connection between form and from the historical and political context in which the Jesuit village was built.

Keywords: Jesuit theater, Anchieta, Auto de São Lourenço, theatricality in the colony.

Este artigo é a primeira parte de um estudo em desenvolvimento sobre formas da teatralidade na colônia. Sugestões para seu aperfeiçoamento são bem-vindas. O contato com o autor pode ser feito pelo endereço eletrônico: vintem@uol.com.br.

Certa visão esteticista e dramática do teatro dificulta ainda hoje o entendimento das manifestações que ocorreram no período colonial do Brasil, ampliando um problema gerado pela própria rarefação dos documentos. Grande parte do que poderia ser considerado teatro entre os séculos XVI e XVIII é simplesmente ignorada pela historiografia por não ter ocorrido na forma dialógica de uma "peça."'

A cena produzida pelos jesuítas nas últimas décadas do século XVI, entretanto, é sempre examinada nos estudos de história teatral porque, apesar da condição de produção amadora e instrumentalizada pela religião, atende ao parâmetro de uma cena literária. Bem antes da canonização, Anchieta encarnava a figura heroica de um "primeiro dramaturgo", escritor incomum

1. A aparente ausência de produção ganhou fama no título dado por Sábato Magaldi para o capítulo sobre o teatro colonial dos séculos xvii e xviii, "Vazio de dois séculos" de Magaldi (1997). 
que produziu poesia épica, lírica e dramática em condições adversas e num enfrentamento cultural inédito, em que as formas europeias são modificadas nas condições da colônia nascente. É assim que Galante de Sousa (1960) assinala o que considera um marco:

Seria erro, porém, supor que, antes dos jesuítas, não tivesse havido teatro no Brasil. [...] Por outro lado, não há dúvida de que as primeiras peças de que se tem notícia foram escritas pelos jesuítas, razão por que se consideram marco inicial do teatro no Brasil as representações levadas a efeito pelos catequistas. (p. 85)

Para o historiador do teatro, contudo, a inclusão das peças de Anchieta no cânone gera problemas de toda ordem. Em primeiro lugar, quer queira ou não, será obrigado a reconstituir uma dimensão cênica perdida sem a qual aqueles autos não fazem sentido. Seu conceito de teatro terá que ser problematizado, aproximando-se de um campo que alguns teóricos já chamaram de teatralidade ${ }^{2}$ : terá que pensar a relação do documento com manifestações culturais e de cena não previstas pelas palavras e poderá ser levado a considerar como "teatrais" um conjunto de manifestações que antes identificaria apenas como parateatrais. Terá que fazer, como ocorreu com Décio de Almeida Prado (1993), a análise prévia de elementos "escassamente teatrais" antes de encontrar sua suposta "cena genuína de teatro" e conseguir interpretar o texto analisado (p. 20).

A historiografia, nesse sentido, enfrentará seus pressupostos críticos (ideológicos, formais e produtivos) caso queira tão somente descrever teatralidades coloniais que só podiam ocorrer no âmbito amador e ligadas a uma dinâmica social em que certa modalidade de espetáculo - público e religioso - dependia de formações culturais não especializadas.

Até o início do século XIX, a modernidade dos fenômenos teatrais na colônia passava longe de um sistema aristocrático ou mercantil de entretenimento, com suas casas de espetáculos, elencos estáveis, especialização em tipos e definição de repertório de acordo com gêneros do palco. Estava, como quase sempre esteve, impossibilitada de absorver um conjunto de autores

2. Veja mais a esse respeito em Sarrazac (2000). O autor apresenta o desenvolvimento do debate sobre a teatralidade a partir do pensamento teatral de Roland Barthes e Bernard Dort. 
nativos interessados na representação de temática nacional através da forma dramática, como ocorreu na Europa pós-Renascimento.

\section{Recusa e manutenção do modelo dramático}

É significativo que Décio de Almeida Prado (1993), num dos mais importantes estudos sobre a história do teatro no Brasil, se veja obrigado a suspender os critérios convencionais que balizam a tradição de análise do teatro nacional na era burguesa. No primeiro parágrafo do livro comenta sua decisão:

\footnotetext{
O teatro chegou ao Brasil tão cedo ou tão tarde quanto se desejar. Se por teatro entendermos espetáculos amadores isolados, de fins religiosos ou comemorativos, o seu aparecimento coincide com a formação da própria nacionalidade, tendo surgido com a catequese das tribos indígenas feita pelos missionários da recém fundada Companhia de Jesus. Se, no entanto, para conferir ao conceito a sua plena expressão, exigirmos que haja uma certa continuidade no palco, com escritores, atores e público relativamente estáveis, então o teatro só terá nascido alguns anos após a Independência, na terceira década do século XIX. (p. 15)
}

A hesitação em abrir mão da "plena expressão" de certo conceito de teatro não impede, entretanto, o crítico de se dedicar ao exame da cena jesuítica. E a qualidade de seu comentário, um dos melhores sobre a dramaturgia de Anchieta, extrai energias da percepção de que os autos jesuíticos só têm sentido quando associados às formas ditas parateatrais e a um contexto maior. Conscientemente ou não, Décio segue os passos de uma nova historiografia do teatro europeu, que a partir da década de 1970 percebe que só poderá conhecer aspectos novos do teatro medieval se adotar um "amplo conceito de teatralidade" capaz de incluir atividades do cerimonial eclesiástico e o âmbito das celebrações da vida social da corte e da cidade. Enfim, um teatro que "não tem uma realização textual própria e que tampouco era habitualmente recolhido por escrito" (PÉREZ PRIEGO, 2009, p. 17).

Mas como compreender a encenação jesuítica que modela textos de um autor como Anchieta? A grande maioria dos historiadores do teatro no Brasil que trataram do tema recorre à mesma fonte documental, fornecedora de imagens vivas da época: os escritos do Padre Fernão Cardim. 
No ano de 1583, Cardim, ainda jovem, chegou ao Brasil na privilegiada condição de acompanhante do visitador da Companhia do Jesus, Cristóvão de Gouveia. Sua Narrativa epistolar de uma viagem e missão jesuítica registra as andanças da comitiva do visitador por colégios, casas e aldeias mantidas pela Companhia, entre Pernambuco e São Paulo.

Cardim é de fato um escritor notável, ainda que sua motivação literária seja apresentar o bom sucesso da própria viagem de visitação, em sua capacidade de dinamizar o processo missionário em curso, em contraste com a matéria humana e natural tão refratária e estranha.

Os mais impressionantes registros da teatralidade jesuítica feitos por ele são, portanto, os das festas de recebimento, aquelas em que as aldeias ou a comunidade do colégio se organizam para saudar o visitante ilustre, com procissões, coros cantados, saudações dialogadas, fogos de artifício e representações com adereços. O mote da festa era a doação de alguma relíquia sagrada, sendo que Visitador Gouveia trouxe na mala diversos ossos de santos, enviados pelo Papa, para serem distribuídos como objeto de culto das igrejas em construção.

Praticamente todos os historiadores do teatro no Brasil ${ }^{3}$ reproduziram trechos de Fernão Cardim, um "guia prestimoso nesses assuntos", na expressão de Galante de Sousa, quando se tratava de fornecer alguma imagem cênica complementar aos textos de Anchieta. Um desses relatos, também citado parcialmente por Décio de Almeida Prado, se refere a um incrível recebimento ocorrido em fins de novembro de 1584, em que os índios encenam uma captura guerreira do Visitador, quando chegaram os padres para a festa de Nossa Senhora da Conceição, numa aldeia situada a três léguas de Salvador, na Bahia:

Foi o padre visitante fazer-lhes a festa. Os índios também lhe fizeram a sua: porque duas léguas da aldeia em um rio mui largo e formoso (por ser o caminho por água) vieram [...] com seus tambores, pífaros e frautas, providos de mui formosos arcos e frechas mui galantes; e faziam a modo de guerra naval muitas ciladas em o rio, arrebentando poucos e poucos com grandes gritas, e prepassando pela canoa do padre lhe davam o Ereiupe, fingindo que o cercavam e o cativavam. Neste tempo um menino, prepassando em uma canoa pelo padre Visitador, Ihe disse em

3. Entre os bons estudos sobre teatro jesuítico estão: Hessel e Raeders (1972), Cafezeiro e Gadelha (1996) e Pontes (1978). 
sua língua: Pay, marápe guarinime nande popeçoari?, sc. "em tempo de guerra e cerco como estás desarmado?" e meteu-Ihe um arco e frechas na mão. O padre, assim armado, e ele dando seus alaridos e urros, tocando seus tambores, frautas e pífanos, levaram o padre até a aldeia, com algumas danças que tinham prestes. [...] Acabada a missa houve procissão solene pela aldeia, com danças dos índios a seu modo e à portuguesa; e alguns mancebos honrados também festejaram o dia dançando na procissão, e representaram um breve diálogo e devoto sobre cada palavra da Ave-Maria, e esta obra dizem compôs o padre Álvaro Lobo e até ao Brasil chegam suas obras e caridades. (CARDIM, 1980, p. 166)

Décio de Almeida Prado (1993), inspirado pela citação, sugere alguns princípios dessa teatralidade aberta, toda feita de interações entre a cena e a festa, e que condiciona a dramaturgia de Anchieta:

Temos aí, esboçados por Fernão Cardim, alguns dos princípios fundamentais da encenação - e, portanto, da dramaturgia - jesuítica: o teatro concebido como parte de uma festa maior, que nem por ser religiosa deixa de ter lados francamente profanos e divertidos; o constante deslocamento no espaço (observável também nas festividades indígenas), como suporte de diálogos ocasionais, não necessariamente ligados entre si, que faziam a procissão estacionar por minutos; as figuras simbólicas, quando não sacras (a Sé, a Cidade, o Anjo); o cenário quase sempre natural; os papéis interpretados por alunos de vários níveis, sem exclusão de indígenas; o diabo visto como fonte de comicidade, à maneira indígena (e portuguesa, se lembrarmos de Gil Vicente); a comunicação de natureza sensorial, proporcionada pela música e pela dança, com os instrumentos indígenas de sopro e percussão sendo equiparados aos correspondentes europeus (frauta, tambor); e, antes e acima de tudo, o aspecto lúdico do teatro, entendido como jogo, brincadeira, porta imaginária através da qual entravam com enorme entusiasmo os índios [...]. (p. 20)

Em que pese a ótima enumeração de princípios artísticos não dramáticos, o que se vê na sequencia do ensaio de Décio de Almeida Prado, entretanto, são comentários que pouco incorporam esse conjunto de observações. Ele passa a resenhar os principais temas e figuras das peças de Anchieta, com comentários lúcidos em torno da questão catequética, interpolados por avaliações que tendem à depreciação formal. A dificuldade de estabelecer conexões entre a forma do auto e a teatralidade aberta indicada no próprio texto cria um dualismo analítico, que é resolvido com o apelo a critérios dramáticos externos à obra e oriundos de uma tradição teatral posterior. 


\section{Forma heteróclita do Auto de São Lourenço}

Não cabe aqui refletir sobre as razões desse movimento contraditório no ensaio de Décio de Almeida Prado. O que interessa é constatar que o resumo das principais personagens e características formais de uma peça como Auto de São Lourenço - a mais famosa de Anchieta - não é suficiente para que sua teatralidade possa ser investigada como fenômeno histórico. Algo do sentido real do material escapa à análise do crítico. Ele apresenta bem o cortejo inicial da peça, descreve os demônios tupinambás que aparecem no tablado para estimular os pecados da aldeia (os vícios da bebedeira, luxúria e violência); indica que são esses mesmos índios-demônios que, após a conversão combativa do Anjo, se oporão aos antigos imperadores romanos que supliciaram a São Lourenço e São Sebastião; e destaca bem a dimensão cômica da peça, aspecto importantíssimo da forma e ignorado por muitos. A descrição, entretanto, não vai além dos conteúdos mais evidentes e reitera a fórmula consagrada do teatro catequético. $\mathrm{O}$ crítico chega a sugerir que a confusão da peça decorre de uma livre associação feita por Anchieta em torno do tema do orago São Lourenço, sendo "a unidade dramática das mais precárias":

Já deve ter ficado claro, a esta altura, que a coerência formal, ao contrário da religiosa, nunca esteve entre as cogitações ao autor de Na Festa de S. Lourenço. [...] Buscava-se, como se percebe, um efeito cômico acessível ao público, ainda que à custa da lógica e das regras habituais da dramaturgia. Importava o "recado" [...] religioso, não a estruturação e o acabamento artístico. Mas qual seria esse recado, em relação à área indígena, a mais especificamente visada? Os jesuítas tinham em mira dois fins precisos: substituir uma religião (ou mitologia) por outra e um código moral por outro. (PRADO, 1993, p. 29)

Numa versão sintética do mesmo raciocínio, em Prado (1999), o incômodo com o caráter caótico e episódico da estrutura, e com a simultaneidade espacial e temporal da cena jesuítica, persiste:

É possível que a dispersão desse heteróclito universo ficcional se justificasse, em parte, pelo caráter itinerante do espetáculo, desenvolvido muitas vezes em formato de procissão, com paradas em diferentes 
lugares, cada uma dando origem a um episódio autônomo, dentro do tema religioso geral. (p. 20)

Sem mediações que permitam compreender o "caráter heteróclito" da dramaturgia, o que passaria pelo aprofundamento das conexões sugeridas pelo próprio crítico com base em Cardim (quanto à função do teatro: "a cena é parte de uma festa maior"; quanto à forma teatral: aberta, processional, alegórica), Décio de Almeida Prado combina o juízo de valor particular, amparado em critérios de unidade estética e dramática, a uma observação geral sobre a função daquela dramaturgia no nível temático: substituir o fundamento religioso e o código moral da plateia indígena.

Por trás do argumento, há a ideia de que se trata de um teatro menor por ser instrumental, que subordina dimensão estética à eficácia cômico-religiosa. E em um segundo nível, não nomeado, o crítico parece rejeitar a própria poética alegorizante da peça, ecoando o ponto de vista condenatório do classicismo descrito por Walter Benjamin (1984): "Denunciar a alegoria vendo nela um modo de ilustração, e não uma forma de expressão" (p. 184).

Mas o processo alegórico contido no Auto de São Lourenço, com seu caos metafórico, talvez esteja de fato em um lugar de difícil classificação, intermediário entre o didatismo da alegoria medieval cristã, modelada pela forma do auto religioso, e o sentido místico-histórico-natural, da alegoria barroca. Assume, na verdade, um lugar sem precedentes literários, movido pela pressão de seus temas coloniais imediatos. Nesse sentido, o crítico - e também o historiador do teatro - terá de se perguntar o que essa "precária unidade" (heteróclita e orientada pelo princípio da substituição, como toda alegoria) tem a dizer concretamente sobre as relações entre aquele teatro e aquela sociedade?

\section{Anchieta e a alegoria da aculturação}

Outro caminho analítico também pode ser percorrido por quem procura compreender uma peça como Auto de São Lourenço. Aparentemente mais útil à crítica literária do que à história do teatro, ele permite, entretanto, pensar na possibilidade de uma abordagem interpretativa mais imanente à obra. 
Nesse sentido, o método do ensaio de Alfredo Bosi (1992) seria inverso ao de Décio de Almeida Prado. Bosi procura sondar, através da estrutura linguística e rítmica dos versos de Anchieta, um processo maior da história da cultura. Para o crítico, o trabalho fundamental do poeta Anchieta começaria em moldar, no interior dos códigos tupis, uma "forma bastante próxima das medidas trovadorescas em suas variantes populares ibéricas" (BOSI, 1992, p. 64). Examina, a partir daí, as dificuldades do sistema de correlações culturais nas aproximações dos jesuítas aos índios. Conceitos mais ou menos abstratos para os cristãos, como o "reino de Deus" ou o "demônio", são os que exigem do poeta-missionário um esforço de penetração no imaginário do outro, e geram uma nova representação do sagrado que não é mais teologia cristã nem crença tupi: surgiria assim uma "terceira esfera simbólica, uma espécie de mitologia paralela que só a situação colonial tornou possível" (BOSI, 1992, p. 65).

A partir da procura de homologias, ele levanta a hipótese de que o ponto fundamental de convergência cultural

[...] não se encontrava nem em liturgias a divindades criadoras, nem na lembrança de mitos astrais, mas no culto dos mortos, no conjuro dos bons espíritos e no esconjuro dos maus. Eis as funções das cerimônias de canto e dança, das beberagens (caiunagens), do fumo inspirado e dos transes que cabia ao pajé presidir. (BOSI, 1992, p. 69)

O teatro de Anchieta, portanto, teria sido construído como parte dessa substituição catequética das cerimônias tupi-guaranis em relação aos mortos por uma "liturgia coral e pinturesca que se desdobrava em procissões.' A análise de trecho do Auto de São Lourenço feita pelo crítico confirma essa hipótese. A fala do demônio Guaixará que descreve suas supostas obras malignas (bebedeiras, dança, preparação pictórica do corpo, fumo, sexo livre e antropofagia) surge como uma exposição do sistema ritual dos tupis a ser substituído pela visão cristã e talvez, poderíamos acrescentar, pela própria ordem ritual da cena.

A conclusão ideológica, assim, não deixa de ser semelhante à de Décio de Almeida Prado. O problema maior estaria na veiculação de uma ideologia estética regressiva por parte de um dramaturgo que teria condições de fazer diferente: "A pedagogia da conversão apagava os traços progressistas virtuais 
do Evangelho fazendo-os regredir a um substituto para a magia dos tupis" (BOSI, 1992, p. 93).

Sua avaliação negativa da experiência teatral de Anchieta é apresentada em contraste com considerações positivas sobre a poesia lírica do padre. A lírica, ao expressar o sentimento religioso individual, seria construída por Anchieta de forma mais moderna, não ilustrativa, enfim simbólica. O teatro de catequese, ao contrário, seria voltado para as exterioridades da religião e concebido a partir de um código para uso do povo (e não uso próprio), promovendo um pacto arcaizante com a forma aleg órica a serviço da legitimação do poder: "A alegoria foi o primeiro instrumento de uma arte para as massas criadas pelos intelectuais orgânicos da aculturação" (BOSI, 1992, p. 81).

Não há dúvida de que aqui o conceito de alegoria é goethiano, ou seja, o de forma de uma ilustração abstrata do conceito, portanto oposta à unidade concreta do "símbolo". Para Bosi, seria problemático trabalhar com uma leitura transformadora dessa tradição idealista, como a proposta por Walter Benjamin - para quem a alegoria pode ser também forma reveladora da desumanização (e não necessariamente mistificadora) -, porque o caso do auto anchietano é o do apassivamento do espectador, da imposição de uma fórmula de legitimação hierática do poder.

É preciso concordar com o crítico se acreditarmos que o teatro colonial foi, em termos absolutos, uma ferramenta de aculturação. Mas seria mesmo essa a função fundamental daquele teatro que, de algum modo, participou do massacre? A hipótese da substituição cultural permite entender uma peça como Auto de São Lourenço? E, se permitisse, que culturas de fato estavam em tensão? A visão do conflito exposta dessa maneira omite as cisões e imperfeições de um material que, mesmo sendo organizado em torno de um projeto de conversão e doutrinação, alegoriza - até mesmo por suas irrealizações teatrais - questões mais amplas e contraditórias da vida cultural na colônia no fim do século xVI. Apesar dos esforços em sentido contrário, surge de novo, mesmo nos melhores estudos, a falsa imagem de um embate dualista entre os ritos dos padres e os dos índios na floresta, entre culturas de identidade definidas, a católica de um lado e a indígena de outro, oposição sintetizada numa fórmula equivocada - teatro catequético - que não ilumina a forma nem os materiais da peça. 


\section{Forma do auto, forma da festa}

A maior dificuldade para os estudos do teatro na colônia está na exigência de uma concretização reflexiva de um objeto fugidio (o trabalho teatral) que pressupõe a articulação de várias dimensões: temas, forma cênica e literária, situação produtiva e função social. E isso não se faz sem a crítica das próprias categorias analíticas. Sem que o lugar social daquele fenômeno estético se apresente, indicando a inter-relação do conjunto de fatores em seu movimento histórico, os produtos artísticos pouco dirão sobre os processos históricos e culturais em questão.

Quando nos perguntamos sobre o lugar social da peça Auto de São Lourenço, são muitos os caminhos possíveis a percorrer. Poderíamos, por exemplo, retomar a sugestão de Décio de Almeida Prado e, ainda dentro do campo das manifestações da cultura, pensar o que significa o "teatro como parte de uma festa maior." A proposta poderia ser tornada mais complexa se nos perguntássemos também de que modo essa festa é internalizada pela estrutura da peça. Façamos esse trajeto de analogias culturais à procura de seu limite. Ele aparece, por exemplo, na hipótese de um dos principais editores modernos dos escritos de Anchieta, o Padre Armando Cardoso. Ao contrário da crítica convencional que procura relacionar a estrutura do auto às formas antigas das moralidades e milagres do teatro religioso medieval, Cardoso sugere que algumas peças de Anchieta imitariam formas de uma tradição festiva não europeia.

Como se sabe, a cena central do Auto de São Lourenço, em que aparecem os índios-demônios, é uma variante de um texto anterior, o Auto da pregação universal, que foi apresentado pela primeira vez junto à igreja de Piratininga (São Paulo) provavelmente na noite de Natal de 1561 e reencenado diversas vezes pelas vilas e aldeias da colônia. Ao comentar a forma dessa peça, o padre Cardoso sugere um procedimento de adaptação particular: assim como Anchieta se utilizou das melodias de cantigas populares, às quais sobrepunha letras cristãs, teria também feito o caminho análogo na colônia e acomodado formas tradicionais da teatralidade indígena aos temas da doutrina católica. O Auto da pregação universal, assim, seria fruto de uma assimilação: 
$\mathrm{Na}$ feitura de seu Auto, Anchieta inspirou-se nos usos indígenas ao receber um personagem ilustre, com a saudação no encontro longe da aldeia, desfile em caminho novo e engalanado, diálogo na taba, conselho dos chefes, pregação deles sobre o visitante e festa de despedida com dança, música e cantos. (ANCHIETA, 1977, p. 16)

Tal hipótese estimula a imaginação, mas é discutível. Como visto no fragmento de Cardim acima citado, o Ereuipe recitado das canoas era uma expressão tradicional de cumprimento ao visitante, mencionada por mais de um cronista, e provavelmente conduzida por um morubixaba. "Vieste?", era a fala do principal da aldeia, numa pergunta convencional que dava início a um "colóquio de entrada ou chegada". A transcrição feita por Jean de Léry (1980) de um desses diálogos ocorrido com os tupinambás do Rio de Janeiro sugere os termos iniciais:

- Erejúpe? [Vieste?]

- Pá, ajú [Pois não, eu vim]

- Te! Augé nipó Marápe nde réra? [Eis aí, muito bem. Qual o teu nome?] (p. 275)

A forma mais recorrente de acolhida entre os tupinambás, entretanto, da qual o Ereiupe podia fazer parte ou não, era a saudação lacrimosa, estudada por Métraux (1979), em que o estrangeiro ou visitante era rodeado por mulheres na oca de seu anfitrião, que o tocavam, abraçavam-no, cobriam-lhe o rosto com o cabelo e caíam em choro, ao mesmo tempo em que entoavam cantos ou recitavam trovas (p. 157).

Segundo os relatos dos primeiros jesuítas que andavam por aldeias amigas em situações não festivas, a acolhida coletiva, preparada longe do centro comunitário, era costumeiramente feita por crianças que acompanhavam o trajeto musical dos padres. A dança do ato final do Auto de São Lourenço, feita por curumins em doutrina, alude a isso.

Para Métraux, aquela modalidade de recebimento demonstrada no referido episódio do teatro das canoas de Cardim, quando imitaram um combate na água, poderia ser classificada como uma espécie de "saudação agressiva", em que as demonstrações de hostilidade ostensivamente teatralizadas não passavam, no fundo, de sinais de cortesia. 
É óbvio que, em algum nível, as representações dos jesuítas incorporaram padrões indígenas. $O$ relato desgostoso do Bispo Sardinha em relação ao comportamento dos jesuítas nos primeiros anos comprova que a musicalidade indígena muito interessou aos padres da Companhia e foi utilizada em combinação com o repertório europeu:

Admoestei, no primeiro sermão que fiz, logo que cheguei a esta costa, que nenhum homem branco usasse dos costumes gentílicos [...]; e achei que estes gentios se louvam de serem bons, pois os Padres tocavam seus instrumentos e cantavam a seu modo. Digo que os padres tocavam, porque na companhia dos meninos vinha um padre sacerdote, Salvador Rodrigues, que tocava, dançava e saltava com eles. (LEITE, 1938, p. 106)

Boa parte dos autos de Anchieta escritos depois desse momento apresenta corais cantados. Reuniam coreografia dançada e canto acompanhado de instrumentos. Na teatralidade total dos jesuítas a música era um aspecto central, organizava a forma cênica. Entretanto, é difícil dizer, se isso acontecia com base no estilo que os padres chamavam de "órgão" (corais cantados evidentemente sem o instrumento quando se tratava de procissões - termo usado por eles como diferencial do canto no estilo "cantochão"), ou estariam mais perto dos padrões "dissonantes da razão" de que fala o bispo, assemelhados aos cânticos tribais ritualísticos. Que musicalidade era essa que amalgamava elementos dialógicos e corais, representacionais e processionais, será sempre um aspecto difícil de imaginar.

Contudo, nessa via de mão dupla da pergunta culturalista, a forma do auto parece ser mais devedora de uma modelagem medieval europeia advinda das festas da Coimbra quinhentista, onde Anchieta estudou. Os recebimentos indígenas relatados por Cardim pareciam antes indicar uma assimilação contraditória, por parte dos índios, de algumas fórmulas culturais dos colonizadores. A grande maioria dos recebimentos de relíquias relatados por Cardim parece reproduzir essa tradição europeia nas condições da colônia, sendo seu aspecto distintivo a introdução de certo elementos trazidos pelos nativos ${ }^{4}$.

4. As festas de recebimento tornaram-se muito comuns em países católicos como Portugal e Espanha, associadas à difusão de relíquias de santos (cabelos, ossos etc.). Seu padrão, 
Mas seria possível dizer o que origina o quê? Mais importante talvez seja a pergunta sobre o sentido social da "saudação agressiva", da simulação de uma batalha de canoas que insinua um realismo mais cru no imaginário das alegorias festivas, aspecto que não aparece nas descrições de recebimentos feitas em vilas, fora de aldeias ${ }^{5}$.

Os padrões festivos são parecidos, mas nem o Auto de São Lourenço nem sua peça-modelo foram encenados em celebrações de recebimento, e sim em outra situação comemorativa, o jubileu.

A primeira menção documentada ao Auto da pregação universal indica esse objetivo. A peça foi escrita a pedido de Manoel da Nóbrega para substituir uma comédia popular mais grosseira, certamente feita a partir de um folheto de cordel, que costumava ser representado pelos colonos na igreja em épocas festivas. É o próprio Anchieta (1945) quem relata sua motivação:

salvo engano, nasceu de uma adaptação do modelo das festas públicas de entradas reais ou triunfos - forma processional, também religiosa e de grande teatralidade, reincidente no Brasil Colônia. Relatos da segunda metade do século xvı indicam um padrão que se constitui mesmo como gênero, como se vê pela quantidade de relações de recebimentos publicadas. Sua estrutura formal é mais ou menos a seguinte: uma procissão acompanhada de coros ensaiados aludindo ao tema do santo, ecoando imagens do livro Legenda áurea (Companhia das Letras, 2003) permeada de figuras alegóricas que representam abstrações (fama, justiça etc.), sendo o imaginário clássico misturado com figurações cristãs; figurinos ostensivamente ricos, estátuas sobre andores, pálios, iluminação, decoração com sedas espalhadas pelo itinerário, fogos de artifícios, sendo que o cortejo passa sob grandes arcos triunfais decorados, pintados com símbolos hieroglíficos, construídos para a ocasião. Além da presença do teatro de comédias ou de cenas religiosas sobre tablados colocados próximos às igrejas. Veja, por exemplo, o relato de Manuel de Campos intitulado Relacion del solemne recebimento que se hizo en Lisboa a las santas relíquias que se llevaron a la yglesia de San Roque, de la Compania de Jesus, a veinte y cinco de Enero de 1588, citado em CARVALHO, 2001.

5. "Trouxe o padre uma cabeça das Onze mil virgens, com outras relíquias engastadas em um meio corpo de parta, peça rica e bem acabada. A cidade e os estudantes Ihe fizeram um grave e alegre recebimento: trouxeram as santas relíquias da Sé ao Colégio em procissão solene, com frautas, boa música de vozes e danças. A Sé, que era um estudante ricamente vestido, Ihe fez uma fala do contentamento que tivera com sua vinda; a Cidade Ihe entregou as chaves; as outras duas virgens, cujas cabeças já cá tinham, a receberam à porta de nossa igreja; alguns anjos as acompanharam, porque tudo foi a modo de diálogo. Toda a festa causou grande alegria no povo, que concorreu quase todo" (CARDIM, 1980, p. 143). Na carta ânua de 1584, Anchieta complementa esse relato, dizendo que nesse cortejo da catedral até a igreja dos jesuítas "estavam as ruas ornamentadas de folhagens e de flores, e de pé, a um lado e outro do percurso, as seguintes figuras: a Devoção, a Paz, a Castidade e o Anjo Custódio desta cidade, que cada qual saudava com sua alocução, as relíquias, congratulando-se com a cidade pela sua sorte venturosa" (ANCHIETA, 1984, p. 343). 
E por impedir alguns abusos que se faziam em autos nas igrejas, fez um ano com os principais da terra que deixassem de representar um que tinham, e mandou-Ihes fazer outro, por um Irmão, a que ele chamava Pregação Universal [...]. E a gente movida com muita devoção ganhou o jubileu, que era o principal intento da obra. (p. 18)

A frase sobre o principal intento do escritor - "ganhar o jubileu" da natividade - indica a conexão da peça com o conjunto cultural. Os jubileus eram as festas cristãs mais importantes organizadas em torno dos dias dos santos padroeiros ou de outras datas autorizadas pelo papa. Tinham ares de grandes celebrações medievais e eram ocasiões de romaria. Permitiam batismos feitos em série, o que ocorreu sobretudo nos primeiros anos da presença jesuítica, a partir de 1549. Anos depois, em 1563, o papa Pio IV autoriza num breve que os jesuítas aumentem o número desses "jubileus da conversão".

Quando da encenação do Auto de São Lourenço, em 1587, a prática estava instituída e disseminada. Os jubileus tornaram-se celebrações voltadas para que a comunidade cristã pudesse confessar e comungar, confirmando seu pertencimento à cristandade. $O$ simples batismo dos índios já não era indício confiável da cristianização. A essas festas organizadas pelas aldeias concorriam gente da cidade e das fazendas, bem como os índios e padres das demais aldeias da região, sendo que todos participavam da procissão, com tambores, bandeiras e demais aparatos, após serem recebidos pelos índios principais que se vestiam à portuguesa. As representações teatrais, corridas de cavalos com argolinhas e eventuais touradas seriam complementares ao congraçamento religioso.

O jubileu pressupunha uma comunidade já predominantemente cristã, acompanhando, nesse sentido, o desenvolvimento dos aldeamentos jesuíticos que os sediavam. Foram a principal justificativa para as encenações jesuíticas feitas sobre os tablados dos adros, pátios externos das igrejas, na segunda metade do século XVI.

A teatralidade religiosa da colônia procurava intensificar uma relação entre pedagogia jesuítica e comunidade, tendência também dominante na Europa. Nos vários centros educacionais criados desde a fundação da ordem em 1540, recorria-se ao teatro como atividade estudantil dos cursos de retórica ou gramática, em festas de fim de ano ou de abertura das turmas de latim. 
Não por acaso, os professores dessas matérias se tornaram os principais dramaturgos da Companhia. Em pouco tempo, entretanto, esse teatro se expandiu, extrapolou o espaço do colégio e as datas do calendário educacional, e se tornou uma atividade oferecida à comunidade em geral. As representações passaram a se ligar às festas dos santos padroeiros das cidades, ocupando as praças, num estreitamento de vínculos e de favores com as autoridades políticas e o clero secular ${ }^{6}$.

No Brasil, o teatro escrito por Anchieta surgiu fundamentalmente como atividade pública ligada à elite colonial, sempre em ocasiões em que o colégio ou os missionários das aldeias procuravam dialogar com o conjunto daquela sociedade - não apenas com os índios. A compreensão desse fenômeno, ainda que através de uma perspectiva apenas estético-cultural, nos afasta cada vez mais do estereótipo de um teatro catequético em que os dois termos da relação são os missionários cristãos e a plateia indígena selvagem.

Como parte do jubileu de um santo padroeiro do aldeamento - e foi esse o caso do Auto de São Lourenço -, o teatro fazia parte de um evento social em que, durante o tempo da festa, ocorria um deslocamento simbólico: a comunidade de índios cristianizados, situada nas periferias ou adjacência das vilas, centralizava momentaneamente as atenções do conjunto da colônia. Portanto, o teatro dos jesuítas só ocorria mediado por uma história anterior de formação do aldeamento, sem qualquer espécie de virgindade no contato cultural. Não estavam em jogo interações originais, mas confirmações simbólicas de vários tipos, sendo que a religiosa (materializada, a rigor, na comunhão) era apenas uma delas.

\section{Aldeamento e catequese}

Em 1549, pouco tempo após a chegada do primeiro grupo de jesuítas com Tomé de Souza, as lideranças jesuíticas sabiam - a convicção é enun-

6. "Em Sevilha, em 1562, a representação da festa de Deus se desenvolve perante um público [...] números entre os quais se podia ver os membros do tribunal da Inquisição, e outras pessoas de condição. Que as representações tenham sido fortemente apreciadas pela alta sociedade sevilhana, não é preciso enfatizar, se considerarmos que o Conselho Municipal de Sevilha não somente participou das despesas, mas ainda dedicou especial atenção aos preparativos das festas, convidando o Arquiduque, o Regente e a Audiência" (ROUX, 1968, p. 485). 
ciada por Manoel da Nóbrega - que a tarefa missionária da cristianização dos nativos não seria só de ordem ideológica. Nos termos de Serafim Leite (1938), a conversão não era uma "questão doutrinária; era questão de costumes" (p. 12).

O regimento trazido por Tomé de Souza por ordem de D. João III (rei que se empenhou numa política cultural católica moderna e repressiva, antijudaica, anti-islâmica e antiprotestante) afirmava a necessidade de um trabalho conjunto entre Estado e religiosos e já ordenava que os nativos cristianizados fossem afastados de seus grupos originários ${ }^{7}$.

Alguns anos se passariam até que o projeto dos "descimentos" dos índios - que previa sua realocação para uma comunidade cristã controlada - se expandisse e se regulamentasse na forma de aldeias (a rigor, aldeamentos), o que só se deu com o apoio imprescindível dos capitães da coroa. Aquela modalidade de aldeia tutelada despertava irritação nos negociantes portugueses, que preferiam ver no mercado os índios "de resgate", aqueles aprisionados em combate por tribos contrárias, e não em comunidades controladas por padres.

A associação entre catequese e aldeamento tornou-se assim uma prática fundamental para os jesuítas, o que não se deu sem hesitações de ordem filosófica, como se vê no Diálogo da conversão do gentio, escrito entre 1556 e 1557 por Nóbrega, espécie de drama intelectual sobre o trabalho de persuasão moral e espiritual. A constatação incerta da personagem Gonçalo Álvares, de que "trabalhamos debalde ao menos até que este gentio não venha a ser muito sujeito e que com medo venha a tomar a fé", encontrará mais adiante a réplica do personagem Mateus Nogueira: "Humanamente como homens assim falando, este parece o melhor e o mais certo caminho" (NÓBREGA, 1954, p. 85).

A manutenção da fé pela chamada sujeição moderada (expressão utilizada por Nóbrega) será o fundamento do sistema colonial de catequese. "Se Sua Alteza quer ver todos convertidos, mande-os sujeitar", pediu explicitamen-

7. "Porque a principal coisa que me moveu a mandar povoar as ditas terras do Brasil, foi para que a gente dela se convertesse à nossa santa fé católica [...]. Que trabalheis muito por dar ordem como os que forem cristãos morem juntos, perto das povoações das ditas capitanias, para que conversem com os cristãos e não com os gentios." (Regimento de Tomé de Sousa em Albuquerque, 1989) 
te o padre (LEITE, 1938, p. 216). Esse apelo só foi realmente ouvido por um governador que enxergou uma grande utilidade política na técnica de fixação dos índios em comunidades híbridas.

Militar, letrado e talvez mais culto do que a média (entre seus 12 irmãos estava o literato humanista Sá de Miranda), foi Mem de Sá quem entendeu que "sujeitar toda a costa" era uma forma de criar resistência às invasões francesas ou corsárias e também de organizar um contingente de soldados para as guerras locais. Após a conturbada gestão de Duarte da Costa, Nóbrega saúda a chegada do novo governador em 1559, numa carta a Tomé de Souza, destacando o sucesso das fusões de grupos tribais na aldeia do Rio Vermelho, na Bahia e o estabelecimento das grandes aldeias do recôncavo. Os fazendeiros já não podiam dispor livremente da mão de obra sem o freio da coroa e dos jesuítas: "O ajuntar dos índios que o governador faz, para meIhor se poderem doutrinar, deu também muita ocasião de escândalo a muitos que tinham índios perto de suas fazendas, dos quais se ajudavam em seus serviços" (NÓBREGA, 1988, p. 208).

Eram anos em que a instabilidade guerreira se ampliava na costa, a partir da intensificação do comércio e da pressão dos conflitos internacionais decorrentes da disputa pelos pontos de extração de pau-brasil e da mão de obra para a nova indústria canavieira. O tráfico de gente alastrou-se, assim, de modo inédito, difundindo-se o hábito entre os índios de vender suas presas de guerra, antes apenas sacrificadas em rituais antropofágicos.

Nesse contexto de convulsões, após uma onda de ataques em que os próprios aliados tupiniquins se dividem, Anchieta (1984) escreve na Piratininga de 1563:

Parece-nos agora que estão as portas abertas nesta capitania para a conversão dos gentios, se Deus Nosso Senhor quiser dar maneira, com que sejam sujeitados e postos sob o jugo. Porque para este gênero de gente, não há melhor pregação que espada e vara de ferro, na qual mais que nenhuma outra é necessário que se cumpra com o compelle intrare. (p. 195)

Se em Piratininga, ao que parece, alguns índios aceitaram voluntariamente a sujeição à disciplina e ao sistema de proteção da aldeia próxima ao colégio, esse fato ocorreu em face da situação belicosa da colônia. A doutrina 
cristã agora estava garantida por uma repressão interna da aldeia, estando os índios em "contínua doutrina, de dia às mulheres, de noite aos homens, havendo um alcaide, que os obriga a entrar na igreja" (ANCHIETA, 1984, p. 194).

Na Bahia, o próprio Mem de Sá contribui para a pregação baseada na espada e vara de ferro ao ordenar a construção de troncos e pelourinhos em todos os aldeamentos, "para lhes mostrar que têm tudo o que os cristãos têm, e para o meirinho meter os moços quando fogem da escola" (LEITE, 1938, p. 62).

As formas de controle do cotidiano dentro de aldeamentos no século Xvı foram violentas, sempre havendo a participação de índios no processo. Mesmo nas aldeias em que não havia residência fixa de um jesuíta, as visitas às missas ou práticas eram diárias. Havia nos aldeamentos cerca guerreira, pelourinho, igreja e escola; e as funções de justiça, repressão e organização eram organizadas pelos próprios índios: havia o porteiro que controlava a cerca, o alcaide ou meirinho, que também cuidava das querelas e das contravenções, e o ouvidor.

O aldeamento - com distribuição do espaço bem diferente de uma tribo tradicional - radicalizou as práticas convencionais da igreja católica de participar de todas as instâncias fundamentais da vida comum. Se numa igreja de vila europeia do século xvı, a religião definia os padrões da vida coletiva, intermediando nascimento e morte, sinalizando - no repique do sino - o transcurso do tempo ordinário das horas e o do tempo extraordinário da guerra, do incêndio e da peste, servindo ainda como refúgio das calamidades ou como centro recreativo da vida pública - porque "todos os atos estão saturados de religião", nos termos de Lucien Febvre (1978, p. 45) -, no aldeamento colonial sua função era algo mais incisiva: a sujeição a que os índios cristianizados teriam que se submeter "de boa "vontade", gerenciando a própria estrutura punitiva, não era apenas uma entrada conflituosa na civilização cristã (ou na polícia, palavra vibrante que definia a cultura civilizada da época). Estava em jogo uma mudança estrutural dos padrões de vida e de cultura.

A habitação coletiva das grandes ocas indígenas, em pouco tempo, cedeu lugar às casas pequenas. Em 1559, o padre Antonio Blasquez, no esforço de declarar o sucesso da conversão, relata que isso acontecia por opção: “

Os índios desta vila de São Paulo querem em tudo mudar seus costumes e começam agora os que já são cristãos a fazer casas separadas 
e de taipas para viverem nelas, porque o seu costume dantes era cada dous ou três anos renovarem as casas, mudando-se para outras partes. ${ }^{8}$ (AZPICUELTA NAVARRO, 1988, p. 250)

A mobilidade tradicional dos grupos tribais da costa, sua tendência migratória, teria de ser abolida, o que não se deu sem muitos conflitos na medida em que isso alterava o fundamento da relação com a terra e com o conjunto da natureza. Foi através dessa dessocialização dos grupos para uma refundação mítica de sua relação social e cultural diante de um território estável que os jesuítas construíram seu espaço de interações simbólicas, relação complexa que não se resume à ação de catequese. Seria preciso estabelecer um novo fundamento transcendental para o sedentarismo, novas identidades de grupo conectadas aos novos costumes do trabalho. Assim, os aldeamentos geraram uma diferenciação sempre pouco nítida para os colonizadores entre os trabalhadores escravizáveis e os não escravizáveis. Talvez tenha sido essa a percepção "fina” do governante Mem de Sá: se esses cristãos sujeitados têm alguma função para o colonizador, ela terá de ser construída interna e externamente. E sua aposta, ao certo já amadurecida em Portugal, foi no sentido de especializar os índios aculturados em um trabalho não menos importante que a extração de pau-brasil e a produção de açúcar, sustentáculo da troca comercial: a defesa militar.

Luís Felipe de Alencastro (2000), ao comentar o processo de descimentos, em que o "estancamento do movimento migratório" e a consequente dessocialização tornavam os índios permeáveis à catequese, resume as tarefas das missões em alguns aspectos: a proteção "feita pelos índios mansos contra os índios bravos", a manutenção dos contingentes de mão de obra nas proximidades da vila; e ainda no fato de que os aldeamentos também "circunscreviam as áreas coloniais, impedindo a fuga para a floresta tropical dos escravos negros das fazendas e dos engenhos" (p. 181).

Mesmo que essa última observação valha mais para os aldeamentos do nordeste que para os da Guanabara, onde a população de escravos da Guiné ainda era pequena nos tempos do Auto de São Lourenço, o controle do pro-

8. "Em 1574, repete o Padre Quíricio Caxa que os índios queriam viver em casas próprias e não em malocas, todos juntos" (LEITE, 1938, p. 85). 
cesso local de trato de gente foi uma função importante dessas comunidades na medida em que os capitães eram obrigados a saber quem era escravo "legítimo" ou não. O surgimento da função do mamposteiro dos cativos, pessoa encarregada de arrecadar esmolas para "descer" índios com os padres e distribuí-los por aldeamentos, confirma a hipótese. Mesmo um historiador jesuíta como Serafim Leite enxerga objetivos semelhantes no sistema: "aprendizagem da doutrina cristã; aprendizagem do trabalho; defesa contra os inimigos do Brasil" (NÓBREGA, 1954, p. 37).

Não há dúvida de que esse terceiro aspecto foi o fiel da balança no apoio dado por um governante como Mem de Sá à organização das aldeias jesuíticas. No caso da Aldeia de São Lourenço, a especialização era ainda maior: o grupo de índios ali situado tornou-se conhecido como a mais importante milícia da parte sul do país, sendo monitorada de perto pela Companhia de Jesus e pelos capitães de guerra, sob o controle mais distante da coroa e dos cavaleiros da Ordem de Cristo.

\section{A Aldeia de São Lourenço e os soldados cristãos temiminós}

Nenhum aldeamento no Brasil do século xvı teve história tão ligada à defesa do território português como a Aldeia de São Lourenço. Situada em torno de uma colina ainda existente, em Niterói, onde hoje se encontra a Igreja de São Lourenço dos Índios (agora circundada por uma comunidade pobre da cidade), num tempo anterior aos aterros da várzea, quando a praia estava próxima do morro, abrigava grandes canoas guerreiras prontas para reagir ao invasor que entrasse na baía da Guanabara. Do alto da igreja era possível vigiar tanto a entrada da baía como a cidade colonial do Rio de Janeiro.

Sua principal liderança era um índio temiminó de grande preparo militar que se tornou célebre por sua participação nas lutas de expulsão dos franceses e tamoios da Guanabara e do Cabo Frio: o morubixaba-açú Ararigboia, mais conhecido entre os portugueses pelo seu nome de batismo, Martim Afonso de Sousa.

Quando a peça do Padre Anchieta foi levada à cena no jubileu do padroeiro da aldeia, no dia 10 de agosto de 1587, estavam presentes à comemora- 
ção índios cristãos, religiosos e colonos que se conheciam há mais de vinte anos, num passado comum de combates do mesmo lado da barricada.

Ainda que naquela comunidade houvesse índios cristãos de outras procedências, inclusive ex-cativos de origem tupinambá (os principais inimigos do grupo tribal dominante), o aldeamento de São Lourenço era predominantemente composto por índios temiminós, também conhecidos como maracajás ou margaias.

A história desse grupo é relativamente bem documentada pela crônica jesuítica. No ano de 1555, pediram ajuda aos cristãos para deixar sua base primitiva situada no fundo da baía, na atual Ilha do Governador, na época chamada pelo nome do seu então principal Maracajá-guaçu (o Gato Grande). A intensificação da disputa com os inimigos tradicionais (os tamoios - que se distribuíam por várias aldeias em torno da baía) foi desequilibrada pelo apoio dado a estes pelos franceses de Villegagnon, que chegaram para ocupar também o território. Isso fez que o grupo do Gato, com o apoio de naus dos colonos portugueses do Espírito Santo, emigrasse para essa capitania, onde passou a viver em aldeamentos jesuíticos. O primeiro contato dos temiminós com a religião católica ocorreu, portanto, mais de trinta anos antes da encenação do auto.

Por meio da carta do Padre Luís da Grã, escrita no Espírito Santo em 24 de abril de 1555, sabe-se que esses refugiados constituíram o núcleo de um novo aldeamento coordenado pelo Padre Brás Lourenço, homônimo do santo espanhol que inspirará a futura aldeia da Guanabara:

Fica agora o Padre Brás Lourenço com uma nova ocupação [...]. Chegou aqui um principal que chamam Maracajaguaçu que quer dizer gato grande, que é mui conhecido dos cristãos e mui temido entre os gentios, e o mais aparentado entre eles. Este vivia no Rio de Janeiro e há muitos anos que tem guerra com os Tamoios, e tendo dantes muitas vitórias deles, por derradeiro vieram-no por em tanto aperto com cercos que puseram sobre a sua aldeia e dos seus, que foi constrangido a mandar um filho seu a esta Capitania a pedir que lhe mandassem embarcação pera se vir pelo aperto grande em que estava, porque ele e sua mulher e seus filhos e os mais dos seus se queriam fazer cristãos. (LEITE, 1957, p. 226)

As cartas registram os sucessos e percalços dos maracajás em sua relação com a cristandade: a notícia da conversão do Gato, batizado de Vasco 
Fernandes, a esperança despertada em Nóbrega pelos "bons frutos" da cristianização desses índios e as previsíveis recusas a este processo.

As grandes mortandades decorrentes das epidemias que dizimaram muitíssimos índios entre 1558 e 1559 ajudaram a estreitar as relações entre nativos e jesuítas no culto aos santos defensores da aldeia, em particular àquele que é o protetor das pestes, São Sebastião e ao padrinho dos militares, Santiago.

As crônicas sugerem, ainda, que o Padre Brás Lourenço era especialmente interessado na teatralidade suntuosa e algo delirante dos ritos católicos do tempo da Contrarreforma, tendo participado da expulsão do demônio do corpo do filho do Gato $^{9}$, no que foi reconhecido pelos índios como "um verdadeiro pajé.' Incentivava o ensino de música e oratória, sendo ele próprio conhecido como grande pregador e ensaiador de canto. Amoroso, portanto, de práticas cênicas. E, o mais importante, não eram práticas desinteressadas: envolvia-se pessoalmente em batalhas campais portando bandeiras e símbolos da cristandade e invocando a presença transcendental dos santos guerreiros por meio de chamamentos cantados, como aconteceu em 1562:

Este ano passado, depois que o governador Mem de Sá destruiu a fortaleza no Rio de Janeiro, foi esta capitania mui combatida dos franceses, os quais, entrando neste porto com duas naus mui grandes e bem artiIhadas, se puseram defronte desta povoação [...]. Acudiu o Capitão com todos os mais a se encomendar primeiro a Santiago, como sempre costuma indo a suas guerras, nas quais o Nosso Senhor o favorece com lhe dar sempre vencimento; saiu o padre Braz Lourenço a eles, e tomando a bandeira do bem-aventurado Santiago nas mãos, se foi com eles até ao lugar do combate, aonde houve de uma parte e de outra muitos tiros, dos quais nenhum fez dano aos da povoação. (AZPICUELTA NAVARRO, 1988, p. 366)

Os maracajás eram provavelmente semelhantes em termos culturais aos inimigos tamoios. Falavam a mesma língua e tinham, segundo Jean de Léry, que descreve um grupo "maragaia", as mesmas pedras verdes ou ossos

9. "Tinha Vasco Fernandes, nosso principal, um filho por nome Manemoacu, o qual estava mui doente na aldeia da vila. Estando ele assim em uma noite de grande tempestade 0 tomaram os demônios em corpo, e com grande estrondo o levaram arrastando e maltratando" (LEITE, 1957, p. 239). 
nos lábios furados, e quem sabe o mesmo gosto pelo improviso oral e pela musicalidade que distinguia os tupinambás ${ }^{10}$.

Ainda que seja incerto dizer se os temiminós de Arariboia se constituíram como uma dissidência do grupo do Gato, tentando por algum tempo uma vida independente no sertão, o fato é que já estavam também aldeados em 1562 e viviam sob o mesmo modelo de sujeição cristã. A Aldeia de São João, liderada por Arariboia, estabeleceu-se ao norte da Vila da Vitória, um pouco acima da Aldeia da Conceição (do Gato).

Nessas aldeias de "amigos dos cristãos", o processo policial que marcou a forma geral de aldeamento estava em curso. Há até relatos sobre arbitragem de querelas financeiras entre os índios cristãos: "Quando alguém deve, é trazido diante dele (do índio principal que atuava como ouvidor), e não tendo com que pague, Ihe limita tempo para isso, segundo o devedor aponta. Tem um tronco em que mandam meter os quebrantadores de suas leis e os castigam conforme seus delitos" (AZPICUELTA NAVARRO, 1988, p. 367).

Entre 1563 e 1564, houve a substituição do Padre Brás Lourenço pelo Padre Manoel de Paiva, que passou a residir na igreja de São João, centro do aldeamento de Arariboia. A mudança coincidiu com o período de uma nova peste, a grande epidemia de varíola ("bixigas", nos termos da época), quando as inúmeras mortes, segundo relatórios dos missionários, contribuíram para abalar a unidade da sujeição. Ainda que minados pela força da doença, uma parte dessa aldeia de mais ou menos 400 índios, sob a liderança de Arariboia, no ano seguinte seria convocada pelo governador Mem de Sá para acompanhar a armada conduzida por seu sobrinho, Estácio de Sá, para os combates de retomada da baía da Guanabara, completando o processo iniciado em 1560, quando o governador destruiu o forte da Ilha de Villegaignon e negociou a fuga dos colonos franceses, sem ocupar o território.

As ofensivas francesas e, sobretudo, dos tupinambás, nos anos posteriores à destruição do forte francês, ajudaram a reforçar a percepção de que era imprescindível a ocupação definitiva da Guanabara com colonos e índios aliados.

10. "São havidos estes tamoios por grandes músicos e bailadores entre todo o gentio, os quais são grandes componedores de cantigas de improviso, pelo qual são mui estimados do gentio, por onde quer que vão. Trazem os beiços furados e neles umas pontas de osso compridas com uma cabeça como prego [...]. Costumam-se mais em suas festas enfeitarem-se com capas e carapuças de penas de cores de pássaros” (SOUSA, 1971, p. 110). 
O relato desses temas conhecidos se justifica para observarmos alguns detalhes que aparecem nas peças. A expedição de Estácio de Sá era constituída por combatentes de várias procedências: seis navios traziam colonos de São Vicente, acompanhados por nove canoas de índios de grupos tupiniquins; e foi esta a base da armada à qual se juntaram as canoas dos temiminós de Arariboia. Em pouco tempo, porém, vários tupiniquins abandonam a tropa, tornando-se os temiminós os principais soldados índios. Mais importante, ainda, é destacar o fato de que os únicos religiosos a bordo eram os dois jesuítas que vinte anos mais tarde foram os responsáveis pela encenação do Auto de São Lourenço: o padre Gonçalo de Oliveira, capelão militar que rezou a primeira missa após o desembarque de $1^{\circ}$ de março, ao pé do Morro Cara de Cão, próximo ao Pão de Açúcar; e o ainda irmão, com 30 anos de idade, José de Anchieta.

Na chegada à Guanabara no 1ํ de março de 1565, Anchieta esteve presente durante o primeiro mês do acampamento da Urca. Foi nomeado "conseIheiro" de seu superior, o Padre Gonçalo, que oficiava as missas e confessava os combatentes. Homem de confiança de Nóbrega, que já tinha participado da negociação de trégua com os tamoios em Iperoig (evento que, aparentemente, funcionou como ganho de tempo no jogo de alianças guerreiras para a expulsão dos tupinambás), Anchieta participou do processo de convocação dos soldados índios para a guerra da Guanabara e do planejamento do futuro colégio e aldeamento. Contribuiu, ao certo, para a construção do imaginário em torno de São Sebastião - o santo que nomearia a cidade -, tanto pela decisão do dia da partida da frota de São Vicente, em 20 de janeiro de 1565, como pelas predições sobre a colaboração transcendental no combate. Até mesmo a literatura jesuítica voltada para a santificação do padre dramaturgo destaca seu grande empenho nessas conquistas militares, relatando sua conexão temporal com os índios e a espiritual com os santos envolvidos na luta.

A biografia escrita por seu contemporâneo Pero Rodrigues (1988), por exemplo, retrata os dois anos de acampamento e lutas intermitentes antes do massacre final de Uruçumirim, em 1567, atribuindo o sucesso da causa ao "favor do glorioso mártir São Sebastião, que foi visto dos tamoios, que depois perguntavam quem era um soldado que andava armado, muito gentil homem, saltando de canoa em canoa, que os espantara e fizera fugir" (p. 87). O mes- 
mo texto destaca, entre os soldados dignos de nome, o mais "assinalado", "que sem ele nunca se tomara o Rio de Janeiro, de modo que se pode chamar a honra dos índios cristãos do Brasil. Chamava-se pelo nome português Martin Afonso de Sousa, e pelo da terra Ararigboia" (p. 87).

Após o ciclo de batalhas, com a morte de Estácio de Sá, o processo de constituição da nova cidade de São Sebastião do Rio de Janeiro, agora refundada no morro do Castelo, foi conduzido por Salvador Correia de Sá.

Por meio de documentos da época se percebe o cuidado dos jesuítas em legalizar a sesmaria que Ihes foi concedida pela família Sá, bem como em documentar todo o processo. O Padre Gonçalo de Oliveira cuidou das principais tarefas ligadas à terra para construção do colégio, feitas em paralelo ao estabelecimento do grupo de Arariboia, que ocupou nos primeiros anos o lado ocidental, onde atualmente está o Rio de Janeiro, próximo ao ponto onde o Rio Iguaçu desaguava na baía.

Essa primeira ocupação, conhecida por Aldeia de Jeribiracica ou Ibiraciqua, era também chamada "Aldeia do Martinho", de Martim Afonso, conforme registrada em mapas antigos. Apesar da dotação de terras na banda oriental já ter sido feita em 16 de março de 1568, a mudança e a configuração de um aldeamento jesuítico só ocorreria algum tempo depois.

Também é preciso relatar que nessa mesma documentação há sinais da importância de Arariboia aos olhos da comunidade. Um registro de 1573"1, quando, após querelas com colonos, os jesuítas pedem uma demarcação mais exata de suas terras, confirma que Martim Afonso era, de fato, àquela altura, "índio do habito de Christo", podendo testemunhar nas arbitragens.

Pero Rodrigues (1988) informa que a notoriedade de pertencer à principal ordem militar-religiosa da elite portuguesa, oferecida pelo próprio rei, tinha sido conferida após um episódio em que Arariboia enfrentou com habilidade tática a ameaça de quatro naus francesas que vieram à Guanabara trazendo tamoios que queriam se vingar dos temiminós:

Foi informado El-Rei Dom Sebastião deste bom sucesso, e da valentia de Martin Afonso, e das façanhas que tinha feito e fazia em seu serviço, pelo que the mandou o hábito do Cristo, com doze mil réis de tença, e

11. Os documentos estão reproduzidos em Serrão (2008). 
pelo tempo em diante lhe mandou algumas peças de estima, até Ihe mandar uma vez um vestido de seu corpo, inteiro e acabado. (p. 89)

A distinção do hábito de Cristo é impressionante se pensarmos que o próprio Mem de Sá teve dificuldades em ganhar a mercê régia, só a conseguindo após súplica feita em carta e justificada pela campanha bem sucedida na Guanabara. E obteve ainda a concessão com a advertência dos cavaleiros professos em Portugal: "posto que o governador não justificasse as qualidades que lhe era necessário ter pera ser recebido na dita Ordem" (SERRÃO, 2008, p. 110).

O anedotário em torno desse índio cavaleiro de Cristo Arariboia ainda inclui a solenidade de seu casamento que contou com toda "gente luzida" da Guanabara, sendo os noivos recebidos por Salvador Correia de Sá. Ainda mais eloquente foi sua resposta arrogante ao recém-empossado governador Antonio Salema que assumiu a parte sul do território durante o período de divisão do governo geral ${ }^{12}$.

É quase certo que o novo governador não se indispôs com o morubixaba e que os homens de Arariboia estavam entre os 700 índios que, junto com 400 brancos, participaram da chamada Guerra Punitiva de 1575, organizada por Salema para um massacre de tamoios que, segundo Gabriel Soares de Sousa, resultou em "oito ou dez mil almas" de índios mortos, entrados ou cativos.

Para uma compreensão mais ampla do Auto de São Lourenço é importante entender não apenas esse passado de feitos bélicos do aldeamento temiminó - e a posição especialíssima do grupo de Arariboia em seu histórico de guerras com os tamoios -, mas também o vínculo de trabalho com os jesuítas na demonstração da utilidade pública da Companhia, que, afinal, custava aos cofres da metrópole o redízimo de todos os dízimos do Brasil.

Entretanto, o Auto de São Lourenço foi encenado numa década em que esse conjunto de forças se reajustava. Após a unificação das coroas em 1580, sob o governo de Felipe ॥ da Espanha, teve início uma nova fase na política

12. Diante do comentário de Salema sobre a descortesia da posição das pernas do índio que o visitava no palácio, Arariboia teria dito: "Se tu souberas quão cansadas eu tenho as pernas das guerras em que servi a el-rei, não estranharia dar-lhe agora este pequeno descanso; mas já que me achas pouco cortesão, eu me vou para minha aldeia, onde nós não curamos desses pontos e não tornarei mais à tua corte" (VICENTE DO SALVADOR, 1975, p. 187). 
colonial. A correspondência jesuítica sugere um maior esforço de demonstração de utilidade daquele trabalho missionário, e de aproximação aos valores religiosos dos funcionários e militares da Espanha. A exclusividade entre as ordens regulares acabara em 1586: daquele jubileu de São Lourenço participaram também frades beneditinos, franciscanos e carmelitas, recém-estabelecidos no Rio de Janeiro, que contavam com a simpatia do novo rei.

No ano de 1581, quando não estava totalmente concluída a disputa pelo trono travada entre a casa real espanhola e o postulante D. António (o famoso prior do Crato), houve a entrada de três naus de corsários franceses no Rio de Janeiro, supostamente a mando da rainha de França para defender os interesses do lado português da disputa. Chegaram num momento em que a cidade estava desguarnecida, estando o capitão Salvador Correia de Sá e seus melhores soldados ausentes. Foram, novamente, os índios da Aldeia de São Lourenço, àquela ocasião estabelecida na sesmaria da atual Niterói, que defenderam a cidade do bombardeio. Na carta ânua de 1582 vê-se que Anchieta (1984) - já como provincial da Companhia - se vale do episódio para tornar público "como era benquista a Companhia" a partir de seu vínculo com seus subordinados: "Puseram-se os navios uma légua da cidade. E surtos ali, um padre nosso, que tem cuidado da povoação dos índios, saiu dela com catorze canoas bem equipadas, cheias de gente muito lustrosa, que não foi pequeno alívio para a cidade que tão falta de gente estava" (p. 316).

Dois anos depois, em janeiro de 1583, Salvador Correia de Sá recebe a resposta do rei Felipe a seu pedido de confirmação da carta de sesmaria concedida pelo capitão à "povoação cristã de São Lourenço" do Rio de Janeiro e também a um novo aldeamento jesuítico que surgiu na Guanabara por volta de 1582, talvez como dissidência do primeiro (o de São Barnabé), situado no fundo da baía, próximo ao rio Macacu. A resposta régia à petição é um reconhecimento dessa longa história militar aqui relembrada e do "proveito que esta terra terá com haver muitos índios nela de paz cristãos e para defesa e ajuda que farão" (SERRÃO, 2008, p. 296).

O sentido de uma festa de jubileu ocorrida no aldeamento de São Lourenço, poucos anos após a confirmação da sesmaria, teria de dialogar com esse quadro: era um momento de crescimento da produção açucareira e de maior necessidade de mão de obra, de instabilidade na relação entre jesuítas 
e o novo governador geral Manuel Teles Barreto, de maior presença militar espanhola, sendo a Guanabara um porto de parada na rota para a região da Prata. A dimensão cultural desse fenômeno vai além do imaginário religioso visível na peça, estando também na pluralidade linguística (em que predominam o tupi e o espanhol) e na teatralidade violenta, instável e emotiva.

\section{Catequese das flechas e fogo}

É difícil dizer com precisão quando a igreja da comunidade da aldeia de Arariboia assumiu São Lourenço como padroeiro. De qualquer forma, a eleição precisa ser vista como outra homenagem ao poder, assim como ocorreu com São Sebastião, homônimo do último rei português do século.

Lourenço, diácono originário de Huesca, pertencente à comunidade de Aragão, antiga Hispânia, opôs-se às ordens do imperador romano Valério, sendo queimado vivo sobre uma grelha posta sobre o fogo, no ano de 258 d.C. É, portanto, um santo espanhol. O rei Felipe ॥ difunde seu culto após vencer, no dia de São Lourenço, em 1557, a batalha de São Quintin. Como forma de pagar a graça, edificou o palácio El Escorial com a forma da grelha do suplício. Mesmo antes da unificação das coroas, a grande comunidade de origem espanhola dentre os jesuítas - da qual Anchieta, nascido nas Canárias, filho de bascos, fazia parte - já estava atenta à importância de seu culto.

Representado com a grelha do suplício numa das mãos e a palma dos mártires na outra (há uma bela estátua na capela da Aldeia de São Lourenço dos Índios, em Niterói), sua imagem ainda faz lembrar, aos olhos da população da colônia, o destino do corpo dos capturados em guerras tribais: o moquém. Nesse aspecto pode ser comparado a São Sebastião, militar romano supliciado por flechas - às quais sobrevive, antes de morrer numa fossa - nos tempos do imperador Diocleciano. Corpos mutilados por flechas e fogo, em meio a gritaria, canhonaço, são as imagens fundamentais das guerras coloniais e é certo que a encenação do Auto de São Lourenço fez uso de um aparato cenográfico que se vale desses elementos.

Não é possível esgotar nos limites de um ensaio os muitos pressupostos necessários para contextualizar o Auto de São Lourenço. Novos documentos, ao certo, trariam mais elementos a nosso debate. Hélio Viotti (1987), por exem- 
plo, localizou nos processos de beatificação do Arquivo Secreto do Vaticano confirmações que resolvem divergências que duraram séculos: a data da encenação teria sido mesmo em 10 de agosto de 1587, durante o jubileu de São Lourenço; e o papel real do irmão Manuel do Couto, aprendiz de tupi, foi apenas de ensaiador do espetáculo, e não de autor, como dizem alguns, entre eles Serafim Leite. É também quase certo que o superior daquela aldeia, Gonçalo de Oliveira (nosso conhecido capelão militar da tomada da Guanabara, que se afastou dos jesuítas por anos e foi reintegrado em 1584), participou diretamente do trabalho cênico. E, provavelmente, entrou em cena, assim como João de Sousa Pereira, Francisco da Silva e Antonio de Mariz (p. 172).

Não é possível confirmar essas informações. $O$ célebre Antonio de Mariz (tornou-se personagem de José de Alencar) foi, por exemplo, figura central na vida da cidade, provedor da Fazenda real após a conquista, mamposteiro de cativos e grande proprietário de terras. Tomou armas ao lado de Arariboia em todo o ciclo bélico desde 1565 e foi quem ofereceu as terras de sua sesmaria para a formação do aldeamento de São Lourenço. Se é mesmo fato que morreu em 1584, foi seu filho que entrou em cena, o que não diminui a notoriedade da participação, demonstrando que estamos diante de um fenômeno cujos agentes não eram apenas jesuítas e índios, mas sim as principais figuras da vida pública do Rio, tendo elas a experiência comum na guerra contra tupinambás e franceses.

O espetáculo contou com a participação de boa parte dos padres, noviços e estudantes do colégio situado no morro do Castelo, num tempo em que o grupo de padres passava de dez sob a reitoria de Tolosa, enquanto o de noviços passava de 24, além dos muitos oficiais, agregados e escravos. Os dois aldeamentos jesuíticos da região reuniam, então, aproximadamente 3.000 pessoas.

O Aldeamento de São Lourenço, de longa tradição cristã, em 1583 já contava com duas confrarias de índios cristãos: a das Almas e do Santíssimo Sacramento (LEITE, 1938, p. 328). Na visita de Cristóvão de Gouveia, feita dois anos antes do espetáculo, no dia de reis de 1585, Cardim (1980) registra que, após uma missa cantada "oficiada pelos índios em canto de órgão com suas frautas", ele batizou somente dois adultos "por os mais serem todos cristãos" (p. 170). Mesmo diante de um processo de "descimentos" ainda em curso, o fato é que estamos diante de uma comunidade quase toda cristã, 
num estágio em que as questões da catequese tratavam mais da disciplina punitiva do que da conversão. Foi neste lugar que o auto de Anchieta foi encenado. É com essa situação concreta que ele dialoga.

\section{Auto de São Sebastião}

Como imaginar a teatralidade do Auto de São Lourenço? Como, em termos concretos, conectá-la à festa maior do jubileu? É nesse ponto que uma descrição de Cardim sobre um espetáculo semelhante, dedicado a outro guardião da Guanabara, talvez possa ajudar. A festa de recebimento da relíquia de São Sebastião, osso engastado em braço de prata, ocorreu nos últimos dias de 1584. Dela também fez parte a apresentação de um auto, provavelmente escrito por Anchieta. Segundo Cardim, esse recebimento se iniciou, como quase sempre, por um cortejo em que o "senhor governador com os mais portugueses", após abrirem artilharia, num "lustroso alarido de arcabuzaria”, caminharam acompanhados por tambores, pífaros e bandeiras até a praia. Nessa formação algo militar e festiva, o padre visitador trazia a relíquia, seguido pelos homens da elite local. Entraram numa grande barca embandeirada e ramada, com altar e toldo e "grande aparato de velas acesas", sempre acompanhados pelos coros cantados (chamados de órgãos). A embarcação logo foi cercada por diversas canoas e o conjunto desfilou no mar. No meio das canoas "vinha Martim Afonso, comendador de Cristo, índio antigo abaetê e moçacára, grande cavaleiro e valente, que ajudou muito os portugueses na tomada deste Rio". Após o desembarque, os coros da praia e mar se unificaram, e todos seguiram em procissão com a relíquia sob o pálio. A honra de carregar as varas cabia aos cidadãos mais importantes. A procissão estacionou quando chegou à Misericórdia:

Estava um teatro à porta da Misericórdia com uma tolda de uma vela, e a santa relíquia se pôs sobre um rico altar enquanto se representou um devoto diálogo do martírio do santo, com coros e várias figuras muito ricamente vestidas; e foi asseteado um moço atado a um pau: causou este espetáculo muitas lágrimas de devoção e alegria por representar ao vivo o martírio do santo, nem faltou mulher que não viesse à festa. (CARDIM, 1980, p. 169)

O mesmo palco da cena de martírio do moço asseteado foi usado para a pregação de um religioso, que veio a seguir. Ela relembrou a ajuda de São 
Sebastião nas guerras passadas, os "milagres e mercês que tinham recebido deste glorioso mártir na tomada deste rio", seguida de beijação na relíquia sagrada e mais procissão morro do Castelo acima, até a proximidade da igreja dos jesuítas, onde se viu a "mais aprazível" dança de meninos índios, "todos nuzinhos" com seus cascavéis nos pés e com várias invenções de diademas de penas, colares e braceletes.

Na descrição de Cardim, o pequeno Auto de São Sebastião corresponde a uma fase intermediária em que os participantes da procissão se tornam plateia de uma coreografia sacra. Existe um relato de Padre Anchieta (1984) sobre o efeito causado por outra dessas encenações apresentada diante de relíquias (no caso, crânios das Onze Mil Virgens), em Salvador, em 1584, quando estudantes da recém-fundada Confraria das Onze Mil Virgens fizeram a encenação:

[...] corpos degolados e cobertos de sangues das Santas Virgens, carregados pelos Anjos, foram entregues ao sepulcro entre suaves canções. Isso tudo com tamanho realismo que, não apenas os espectadores, mas os próprios atores, deixando-se dominar pela compaixão, desataram em prantos. (p. 368)

É difícil de se avaliar se o efeito despertado por essa espécie de realismo - dos corpos ensanguentados ou do jovem ator flechado -, sustentado por suaves coros, era mesmo a comoção religiosa como queriam os padres. No caso de São Sebastião, entretanto, a imagem do passado em Roma é logo associada, através do discurso do pregador, às conquistas temporais das recentes guerras coloniais.

Surge aí uma teatralidade necessariamente diversa do teatro religioso medieval europeu e da simples "substituição" de ritos. A aculturação, nos casos aqui mencionados, já estava em outra fase por força da sujeição do aldeamento e da história de participação no trabalho de guerra. Trata-se antes de uma comemoração ambígua de uma participação no espaço e no tempo de um território que precisa ser sacralizado em termos diversos do espaçotempo da tradição temininó. A festa surgia como lembrança da utilidade do aldeamento, feita para "espanhol ver", em que a cena aludia ao próprio aparato técnico e militar em posse daquela comunidade. Entre a alegoria e o realismo 
cru, entre a coreografia e a oratória, entre a cultura militar e a indígena, a teatralidade cristã colonial se move do mar para a terra, das canoas para a praia, num trânsito que confunde épocas e lugares, numa mistura de canhonaço e percussão de festa, para logo se organizar como procissão piedosa cujo centro é o andor do santo padroeiro. O público participante desse espetáculo vive o processo de condução dos protetores do território (o São Sebastião que pulava entre as canoas na guerra com tamoios se confunde com os soldados ali presentes), até a parada dramática de concretização sensorial da imagem.

No caso do Auto de São Lourenço, feito não num festejo de recebimento mas num jubileu, esse momento de parada dialógica será algo diferente, ainda que o conjunto processional seja semelhante. Seu auto se desdobrará em mais de uma cena, menos sentimentais e mais violentas, impregnados de um dialogismo diabólico-cômico, de lutas com os santos mártires e com o Anjo em armas, o que produz alegorias contraditórias difíceis de serem unificadas no cortejo final de exaltação do santo no altar.

\section{Aspectos formais da alegoria do Auto de São Lourenço}

Não é possível dizer se o Auto de São Lourenço foi precedido pela encenação de algum combate naval feito pelo grupo de Arariboia, mas a hipótese não é descabida. As simulações guerreiras eram especialmente apreciadas e praticadas pelos índios da costa; o próprio grupo temiminó se envolvia diretamente na comemoração anual das canoas em luta, relembrando as batalhas do cerco de 1565 a 1567. O texto cita o episódio da inadvertida explosão do barril de pólvora numa canoa temiminó, que afugentou os tamoios e evitou um massacre.

De qualquer jeito, o espírito dessas escaramuças guerreiras estrutura as principais cenas. Isso nos leva a supor que o espetáculo começava, assim como o Auto de São Sebastião, com um cortejo embandeirado que vinha do mar para terra, em que a imagem de São Lourenço, desembarcada, era carregada sob o pálio após estrondosa artilharia combinada a sons de tambores, pífaros e canto coral.

Talvez esse seja um possível prólogo do breve texto que constitui o primeiro ato da peça de Anchieta, cuja rubrica diz apenas "enquanto se representa o martírio de São Lourenço". Quando o santo conduzido pela procissão 
já se aproximava do tablado montado defronte a igreja, ou numa estação intermediária na subida da colina, ou ainda num palco lateral do adro, o público que participou do cortejo carregando o andor avistava um ator vestido de santo, talvez já próximo a uma fogueira real (ou simulada com aparatos de pólvora apenas nos momentos que o texto pede). É quase certo que, durante a apresentação, eles utilizavam efeitos de chama, combinados às tochas e velas carregadas pela multidão em fins de tarde ou começos de noite, o que reforçava a metáfora dominante do santo "assado" que "assa demônios" - movido por um fogo que será também amor e temor de Deus.

Diante da imagem do suplício do fogo, coreografada com algum realismo - na acepção de Anchieta -, as palavras do coro, cantadas em espanhol, em redondilha maior, contendo cinco estrofes de fácil memorização, poderiam ser repetidas por todos:

Por Jesus, mi salvador

Que muere por mis mancillas, Me aso en estas parrillas

Con fuego de su amor

$\mathrm{O}$ assim nomeado segundo ato - que provavelmente acontecia num tablado diferente ou em meio à multidão - é na verdade o início do auto propriamente dito e desenvolve o tema da Pregação universal. Entra em cena um diabo. Como seu nome sugere, algo em seu comportamento ou em seus adereços, figurino e maquiagem remete ao demônio conhecido por todos, o guerreiro tamoio Guaixará, famoso inimigo dos temiminós. Grita em tupi, para que a multidão escute, explicitando o caráter irritadiço anunciado na fala (aqui em tradução de Eduardo Navarro):

\author{
Importuna-me bem \\ irritando-me muitíssimo \\ aquela lei nova \\ quem será que a trouxe, \\ estragando minha terra? ${ }^{13}$
}

13. Além das traduções de Eduardo Navarro e do Padre Cardoso, incluídas em nossas referências bibliográficas, existem outras boas edições do Auto de São Lourenço, a pioneira de Paula Martins (1948) e a Almeida (1954), que versificou as partes tupi e castelhana. 
Anchieta retoma aquele que é o mais popular dos elementos da teatralidade religiosa desde o fim da Idade Média: a cena dos demônios. Surgidas nas representações de milagres e mistérios do século XIII, mostravam um grupo de demônios injuriadores e exibicionistas, com seus jogos acrobáticos, grotescos ou farsescos. As criaturas infernais muitas vezes mimetizavam um animal até serem "domados" ou derrotados pela força de um santo ou anjo ${ }^{14}$.

A novidade do teatro colonial era associar o demônio-chefe a um inimigo real - Guaixará - cujos descendentes ainda viviam em Cabo Frio. A crônica religiosa de Simão Vasconcelos (1977) atribui a esse índio a liderança na resistência tamoia, e cita seu nome no episódio do barril de pólvora (que teria inspirado a tradição da festa das canoas):

Aconteceu no meado de julho deste corrente ano de 1566 [...]. Meteram o resto de sua potencia em 180 canoas bem armadas, guiadas pelos mais destros capitães seus, e da nação francesa (cem destas capitaneava um afamado bárbaro por nome Guaixará, senhor de Cabo Frio). [...] E resistindo-Ihes os nossos valorosamente, apelidando o Santo Padroeiro, de improviso ao disparar de uma roqueira na fúria maior da peleja, tomou fogo a pólvora da canoa, e levantou um incêndio grande, a cuja vista, a cuja vista, como de portento insólito, levantou juntamente um grande alarido a mulher do Principal da canoa contrária, que seguia os nossos (e estes costumam embarcar consigo em semelhantes atos) dizendo a vozes, que havia um incêndio mortal, que havia de consumir aos seus, que fugissem, fugissem à pressa. $E$ foi bastante o espanto desta só índia para meter tal horror em toda a chusma, que não só aquela, mas todas as outras canoas fizeram volta e se puseram em fugida desordenada. [...] Em desembarcando em terra foram (os portugueses e aliados) à igreja, e fizeram ação de graças por tão evidente favor, que atribuíam comumente ao invicto mártir padroeiro: e daqui ficou introduzida nesta cidade a festa das canoas, que até o tempo presente costuma celebrarse todos os anos em o dia do mártir S. Sebastião. (p. 127-128)

14.É essa a primeira fala de Satã no Mistério da paixão atribuído a Arnoul Gréban, texto de 1450: "Quem fez essa mutação? Lúcifer, rei dos inimigos, você grita como um lobo faminto, quando quer cantar ou rir" (FRAPPIER \& GOSSART, 1935). Os nomes desses capetas variavam conforme o interesse temático da peça: provinham da legião do Antigo e Novo Testamento, da mitologia greco-latina (como Plutão) e ainda de fontes diversas, como Pantagruel e outros, o que inclui os nomes de vícios no estilo das moralidades. Nos autos religiosos de Gil Vicente se encontra a versão mais cortês e literária dessa tradição (LEBÈGUE, 1953). 
A aparição do demônio Guaixará evoca diretamente para a plateia esse combate de tomada da terra, estando distante de qualquer alegoria:

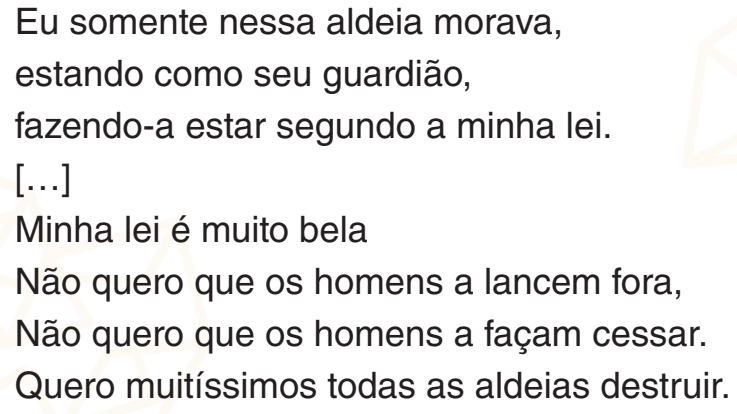

A primeira dimensão da autoapresentação é, portanto, concreta: a de um inimigo histórico que matou parentes dos temiminós, cuja descendência, dispersa pelos sertões do Rio Paraíba e Cabo Frio, poderia ainda realmente ameaçar a aldeia de São Lourenço. É secundariamente que a destruição, encarnada no chefe tamoio, é associada à dimensão dos vícios, segundo a expressão mais abstrata de uma lei a ser superada, a dos antigos costumes tribais:

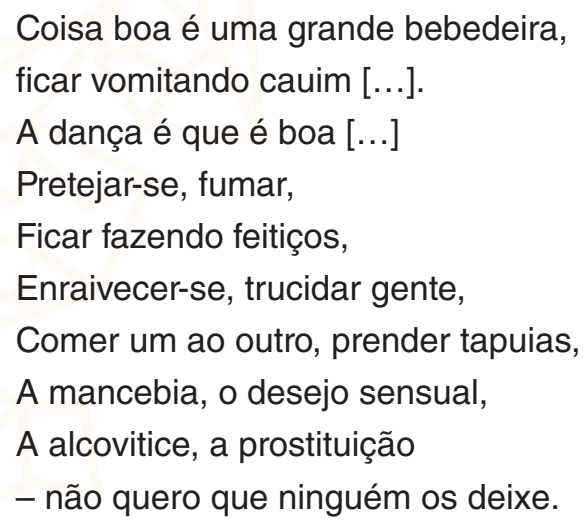

Após a breve autoapresentação, Guaixará recebe a saudação lacrimosa de uma velha fazedora de cauim, que comicamente reclama de seu mau cheiro (possivelmente vindo do pé) e sai de cena. O chefe-diabo logo chama seu "assistente de cena", o não menos famoso morubixaba Aimbirê, que viveu na Guanabara e combateu muitas vezes os temiminós.

Anchieta (1984) conheceu o Aimbirê real durante a negociação de trégua de Iperoig, em 1564, e assim o descreve: 
Veio logo falar-nos com danado ânimo. Este era homem alto, seco e de catadura triste e carregada, de quem tínhamos sabido ser mui cruel, do que contarei um exemplo. Uma de suas mulheres, de umas vinte ou mais que tinha, Ihe fez adultério, à qual tomou e cravou num pau de pés e mãos e com uma espada a abriu pelos peitos e barriga e depois a mandou queimar. Este, pois entrou com muitos dos seus com um arco e flechas na mão, vestido numa camisa, e assentado em uma rede começou a tratar das pazes. (p. 217)

O relato da crueldade parece inverossímil. Contradiz a maioria dos cronistas sobre a relação dos tupinambás com a traição de suas mulheres. Mas o Aimberé da peça é diferente do seu modelo; é menos "danado" e mais próximo de um bufão estúpido. Surge no palco para relatar suas andanças pelas tribos, provavelmente tupinambás, do interior: "Para visitar aldeias à serra eu fui, / para encontrar-me com nossos súditos".

Trata-se do mesmo procedimento de justaposição simbólica: o índio real, guerreiro e considerado violento logo se confunde com o demônio anticristão, farsesco, abstrato, instilador do vício. Sua fala registra nomes das aldeias do interior:

Todos os vícios coloquei bem em seus corações.

[...]

Os que moram em Maratauá

Acreditam em minhas palavras

Todos os que estão na ilha

Todos os habitantes da Paraíba

Em minhas mãos entregando suas almas.

A listagem de inimigos remanescentes não longe da costa - aqueles que seguem no fogo do inferno - prossegue até que Aimbiré deixa de se referir aos "tamoios que se foram para o inferno", mudando a interlocução dramática da peça ao se dirigir aos índios do público presente, habitantes desta aldeia:

Já todos os tamoios foram

estando a queimar no fogo.

Poucos, amando a Deus,

Nesta aldeia moram,

Estando a salvar-se.

Esses temiminós malvados

Nossas leis detestam [...] 
Ao que Guaixará propõe:

Vem para prová-los, pois,

Para que transgridam a palavra de Deus,

Para que bebam cauim para que roubem,

Para que estejam atacando gente,

Para que pratiquem a lei má,

Para que vão para fora desta aldeia.

A enumeração dos costumes "demoníacos", tantas vezes repetida na peça, serve aqui para deixar claro o que está em jogo: pertencer ou não à comunidade de São Lourenço, estar dentro ou fora dela, renovar o pacto disciplinar e punitivo. Não por acaso, a resposta de Aimbiré sobre a dificuldade de realizar essa tentação serve para nomear o guardião do espaço:

- Seu guardião é terrível, espantando-me.

- Quem é ele?

- São Lourenço belo, o que está junto de Deus.

- Qual? Aquele Lourenço tostado, assado como nós?

- Esse mesmo.

Tem início, então, uma mistura de tempos nas falas. Guaixará anuncia que vai enfrentar o Santo, porque já o queimou no passado - referindo-se aos tempos romanos da vida do santo. Aimbiré o previne e menciona a força do companheiro de guerra de São Lourenço (São Sebastião), descrevendo o acontecimento milagroso acima citado:

Vi outrora a grande batalha de Guaixará as canoas eram muitíssimas.

Embora os ajudasse

Irra! Tremeram os malditos...

Os cristãos não eram muitos;

São Sebastião, porém,

Ateou fogo nelas,

Espantando-os. Não ficou

Ninguém no lugar da batalha.

Para finalizar a sequencia de preparativos para o confronto com os santos, os diabos invocam a presença de outro ajudante e chamam um espião 
batedor. Entra em cena o mais ridículo dos diabos da peça, Sarauaia: "Minha coragem ainda existe / Eia, hei de ir longe, / Eu o alegre Sauaia".

Inspirado num traidor real do tempo das guerras, um temiminó ou tupiniquim que passou para o lado dos franceses, o Sarauia da peça é o clássico fanfarrão covarde. Traz na mão uma grande vasilha de cauim, o que sugere que também simulava um bêbado. Sua aparição possivelmente se associa a jogos cômicos físicos: corria em meio ao público e preparava a atenção dos espectadores para a entrada triunfal de São Lourenço, que chega acompanhado do Anjo e de São Sebastião.

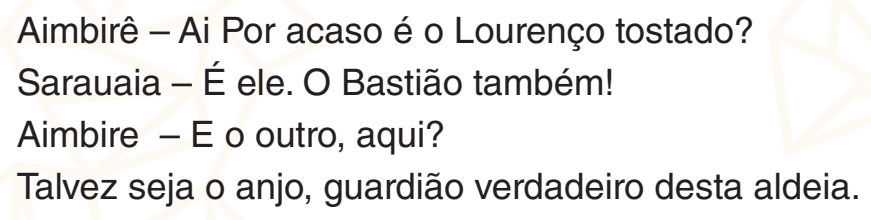

Com São Lourenço, São Sebastião e o Anjo já em cena (figuras hieráticas, ricamente vestidas, às vezes acompanhadas de aparato cênico, como as grandes asas do anjo), tem início uma outra fase da peça. Os diabos se apresentam às figuras divinas como se fossem bichos: Guaixará é cascavel, onça, morcego; Aimbiré é jiboia, socó, sucuri, gavião, tamanduá. É possível que aqui os atores fizessem uso de um jogo tradicional entre índios: a imitação dos sons de animais. O que muda na dinâmica da peça é que os santos, acompanhados do Anjo, debatem com os demônios sobre o real merecimento do público em relação ao amor de Deus. Os espectadores são os réus:

\footnotetext{
São Sebastião - O próprio Deus com sua santidade, As almas deles e os corpos deles fez. [...]

Guaixará - [...] Deus deixou de amá-los, n'Ele confiando muito fracamente.

Aimberé - Nas igaçabas o cauim transbordante, além disso os atrai [...] Nas suas bocas, somente, a crença em Deus está.
}

O breve momento teatral que começa a partir daí tem algo de farsesco e violento (como quando Sarauia treme de medo, fingindo dormir e São Sebastião ameaça flechá-lo até que Guaixará o "acorda" com muitas chibatadas), conectando os debates morais a uma situação física que alude à maneira 
concreta de se tratar o problema dos excessos praticados na aldeia: com punição no tronco e pelourinho. A pregação para convertidos não é aqui, portanto, catequética, abstrata nem puramente cultural. $O$ excesso alcoólico, de ecos rituais, é condenável por produzir brigas violentas e estupros. Não era só caso de consciência, mas de punição pelo sistema interno de justiça do aldeamento. A peça lembra à comunidade cristã, incluídos aqui os colonos, que a sujeição depende da manutenção de uma rígida disciplina (lembremo-nos de como os jesuítas do Brasil se "disciplinavam" agredindo o próprio corpo, até mesmo em praça pública, como forma de domar os desejos e pagar pecados). A comunidade deve se unificar diante dos inimigos: um transcendental, o demônio; outro temporal, as nações inimigas - sendo a disciplina uma necessidade do trabalho militar. As frases da peça desde sempre consideradas catequéticas são, assim, especialmente direcionadas às lideranças cristãs da plateia, o que inclui índios e capitães. Numa fala como a seguinte, talvez o ator apontasse e repreendesse - com efeitos cômicos - o índio principal, Arariboia:

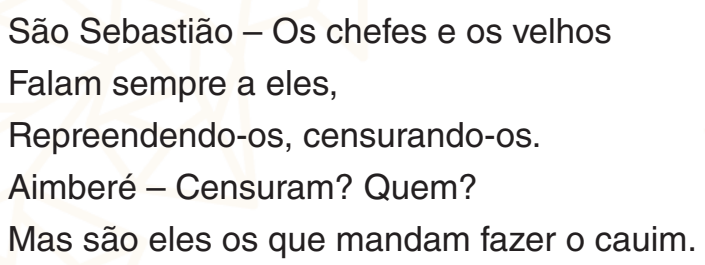

No plano temporal, trata-se de não afrouxar a sujeição coletiva. No plano religioso, trata-se de ganhar o jubileu: São Lourenço lembra ao público que "existe a confissão, remédio portador da cura; as doenças da alma do homem com ela saram bem; em seguida a ela, a comunhão".

Numa comunidade quase toda batizada, os mutirões de confissão e comunhão serviam para confirmar o pertencimento à cristandade. Os demônios e santos da peça, nesse sentido, testam comicamente o vínculo do público com a fé (num jogo irônico de "tentações"), desconfiando daqueles da plateia que escondem seus pecados. Após as acusações, São Lourenço se apresenta como seu defensor:

São Lourenço - Eu não me afasto deles [...].

Em mim confiam, 
Fizeram esta igreja,

Modificando a vida antiga,

Tomando-me como seu guardião,

Bem em mim apoiando-se.

O edifício da igreja, construída pelos próprios índios, como que deixa o fundo da cena e assume primeiro plano. A partir daí há uma mudança na teatralidade. Guaixará grita que irá retirar o público das mãos do santo porque "voa como o vento" e fará todos voarem com ele. Aimberé, após uma mudança de figurino, apresenta agora novos adereços mais conformes aos diabos europeus: "Aimberé - Eis aqui meus chifrões, meus dentes, / Sim, eis aqui também minhas garras, / Meu rabo comprido, meus ganchos".

A cena muda: aparatos cênicos, talvez um guindaste primitivo, e a sonoplastia de fogos de artifício anunciam um confronto breve. O Anjo fala pela primeira vez como um combatente que lutará pela aldeia: "Anjo - Eu permaneço seu guardião, / Companheiro de São Sebastião, / Ajudante de São Lourenço".

Após uma simulação de combate, os diabos Guaixará e Aimbiré são grotescamente presos e amarrados, talvez com as cordas no pescoço dos escravos ou com elas já presas à cintura como ocorria com os cativos que seriam mortos nas cerimônias antropofágicas. Sarauaia, comicamente, é comparado a vários bichos pequenos. Ao ser chamado para ajudar, permanece escondido e finge dormir, para, em seguida, ser humilhado pelo Anjo. Será tratado como um ladrãozinho barato que rouba casas cristãs, que bebe demais em cena, que tenta fugir, e ainda se jacta de suas presas de guerra (apontadas para os espectadores, numa interação cômica com a plateia). Ele é, enfim, também amarrado, com muito alarido, junto aos outros diabos, em mais uma cena marcial.

O Anjo, então, anuncia a finalização do ato em que os diabos serão queimados. Faz uma longa pregação que relembra que "os inimigos da alma" precisam ser enxotados da mesma forma que foram os da terra:

Anjo - Ele vos fortalece

Ele esses vossos inimigos

De vossas almas enxota-os.

Igualmente

este súdito de nosso Senhor 


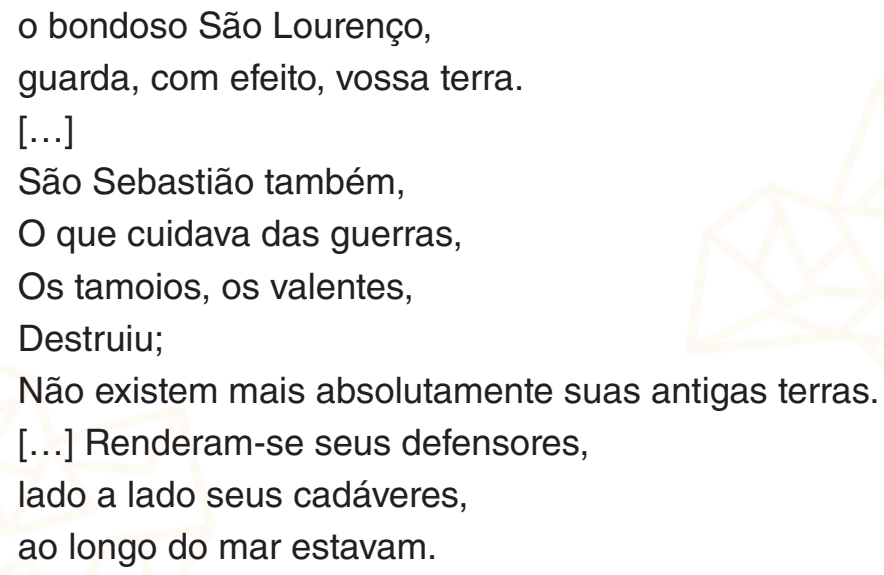

As imagens fortes da mortandade na Guanabara se associam à luta da alma individual, mas o que está em questão é a unidade disciplinar do aldeamento. $\mathrm{O}$ ato se conclui com uma convocatória a que todos cantem e festejem o dia, num canto bélico com ares de vingança, feito diante da fogueira que cresce:

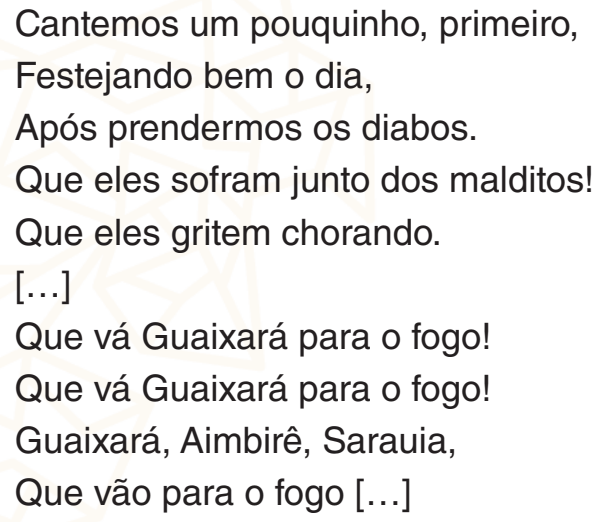

Não é preciso descrever em detalhes os atos que se seguem a essa apoteose de incêndio. É possível que os demônios saiam por um lado da fogueira enquanto São Lourenço retorna para renovar a imagem de seu suplício. As cenas seguintes podem ter sido feitas, inclusive, sem continuidade, logo após um intervalo, um banquete ou uma missa.

O que se vê no terceiro ato é uma mudança na atitude dos diabos-tamoios após sua passagem pelo fogo punitivo e purificatório. O Anjo entra em cena e convoca Aimberé a outra luta, agora para "apresar" e "enforcar" os imperadores romanos do passado. O diabo-tamoio convoca Sarauia festivamente: "Sarauia, vem para beber cauim! / Depois disso, vamos hoje quebrar a cabeça dos reis". 
Após outra cena cômica do palhaço-covarde Sarauia, em que a bebedeira é associada a uma falsa valentia, ele anuncia que os "velhos reis fedorentos" serão comidos. Convoca mais atores que representam quatro bichosdiabos armados - Tataurana, Urubu, Jaguaruçu e Caburé; eles entram em cena com cordas, tacape e adereços para um sacrifício antropofágico, se apresentando através de nova série de imitações animais.

A hoste "se agacha", como diz a rubrica, e se aproxima (ou acompanha a entrada) dos imperadores Décio e Valeriano já visíveis em algum ponto do espaço teatral. Há uma mudança de código: os imperadores romanos falam o idioma espanhol e comparam o assassinato de São Lourenço a um combate nacional: "Valeriano - El remate, gran señor, / Fe esta tan grande hazaña, / Fue más que vencer España”.

Os imperadores percebem a aproximação do grupo de diabos-índios armados, talvez agora composto por todos os contrários. Além dos objetos citados, parecem carregar uma tocha na mão e talvez a grelha e palma de São Lourenço. E é possível que os santos e anjo guardião observem tudo de perto.

Os diabos são confundidos - o que não se dá sem algum efeito cômico - com um grupo liderado pelo deus Júpiter. As demonstrações excessivas de valentia guerreira surgem agora na boca dos imperadores, enquanto temem a aproximação coreográfica do fogo: "Valeriano - Porque Lorenzo Cristiano / Asado nos asará".

Quando o confronto se aproxima, Aimbiré afirma, em tupi, que será agora "castelhano". Em seguida, muda o idioma e diz, já em espanhol, que quer ser castelhano "e se fingir de polícia" com os imperadores, isto é, demonstrar sua civilidade, sua urbanidade ao tratar com os inimigos romanos. Ao que se segue um elogio ambíguo: "porque espanhol ufano sempre guarda a cortesia". Inesperadamente, Valeriano responde em língua guarani, o que gera uma piada de Aimbiré (“Vieste do Paraguai, pois falais em carijó?"), e ordena a Sarauia o ataque.

O que ocorre em seguida é uma coreografia de captura em que os imperadores são estilizadamente presos nas cordas e dispostos em algum aparato de suplício. Aimberé comenta o "pulso alterado de Décio" e seu sangramento iminente (talvez representado com algum recurso de tinta). Os textos mais longos de lamento dos imperadores punidos correspondem ao tempo da coreografia. Tambores, ou mesmo sons de tiros, podem ter se combinado na 
preparação do dispositivo do novo suplício de fogo, até o anunciado "frenesi". Sarauia comenta, em espanhol, que esperava dar "espantosas punhaladas, mas enfim, nossos tiros deram neles atravessados.' Ainda em espanhol, o imperador Décio se arrepende: "Bem entendo que este fogo que incendeio merece minha tirania". Novamente em tupi, Sarauaia anuncia que as "brasas não falham e ainda hoje os malditos queimam", ao que Décio relata na língua dos índios: "Ah, eis que aqui estou muito quente! Assa-me o Lourenço tostado". A sequencia que depende dessa maquinaria teatral do fogo é concluída com o "afogamento" nas chamas e com a entrega dos corpos aos quatro índios "beleguins", restando em cena Aimberé e Sarauaia, sendo que enfim o primeiro confessa o assassinato dos reis, num confusão deliberada entre arrependimento e necessidade de punição aos pecadores.

No quarto ato, é muito provável que a parte externa do Auto de São Lourenço, feita no adro, se dê em uma apresentação interna, para menos gente, feita no interior da igreja. Esse texto é a base para um longo recitativo lírico feito em português (é a primeira vez que o idioma surge no auto) e espanhol, diante da imagem do corpo de São Lourenço amortalhado, em que a alegoria do fogo é feita em termos religiosos. A recitação tem início quando o Anjo anuncia a duplicidade da metáfora: São Lourenço tem dois fogos moventes, diz ele, numa cena ilustrada pela entrada de atores que agora representam o Temor de Deus e o Amor de Deus. O pecador da plateia, assim como o mártir espanhol, por esses fogos também deve se deixar queimar.

O canto do Temor de Deus é feito todo em espanhol. Nele predomina a lírica devota, diferente da comicidade guerreira das cenas anteriores. Os vícios "tão sem freio" são descritos de modo elevado, sendo a luxúria tratada por "carnal delectación" e voz central, talvez glosada em coro, dirigia-se à alma individual:

\footnotetext{
Oh descuido intolerable

De tu vida.

Está tu alma hundida

En el lodo,

Y tú rieste de todo,

Y no sientes tu caída.
} 
O recado do Amor de Deus também parece alternar lírica monódica e coral. Contudo, é curioso o fato de que mesmo o tom elevado presente na descrição do amor das criaturas por seu criador use uma metáfora mercantil para falar da relação entre Cristo e Deus Pai (o original é em espanhol):

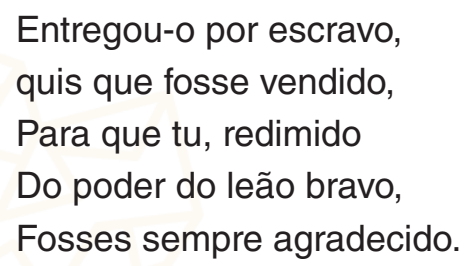

$\mathrm{O}$ ato se conclui numa despedida coral seguida de laus deo, sendo, como tudo indica, a finalização de uma cena que se integra à missa.

O brevíssimo texto cantado do quinto ato promove provavelmente o reencontro final dos espectadores que puderam entrar na igreja com aqueles que permaneceram fora. É enunciado em tupi, com uma letra para ser dançada e cantada por doze meninos, provavelmente os mesmos que participaram anos antes da dança a São Sebastião, acrescidos de novos estudantes da escola jesuítica do aldeamento:

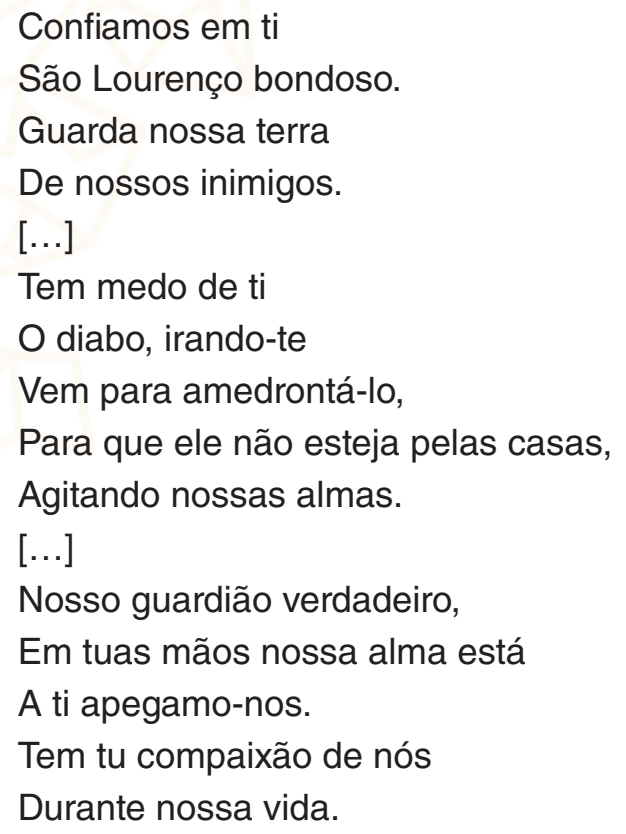

O Auto de São Lourenço é, portanto, uma alegoria complexa. Naquele momento os temiminós do aldeamento eram a principal tropa organizada da 
parte sul do Brasil. Os temas catequéticos da peça não aparecem a serviço da conversão, mas da confirmação da participação no sistema de sujeição do aldeamento. Os temas mais importantes não são voltados apenas à relação entre vontade moral e fundamento transcendental, mas à disciplina coletiva e manutenção da ordem punitiva. O caráter bélico da encenação, quase toda constituída de cenas de combate, expõe um imaginário técnico associado à guerra e dialoga com aquilo que é mais decisivo para a unidade cristã da comunidade: a luta contra inimigos reais e a confirmação de sua utilidade histórica (baseada num vínculo anterior entre jesuítas, Arariboia e Salvador Correia de Sá), diante dos novos representantes da coroa espanhola e da presença das ordens religiosas que chegavam à Guanabara. É como um teatro de polícia (no sentido civilizatório e militar do termo), como um teatro da sujeição ou como um teatro da guerra que os temas religiosos ganham sentido. É justamente sua irresolução estética - diante dos tantos interlocutores que pressionam a estrutura - que a forma alegórica se abre e expressa a barbárie diante do esforço de ilustrar a fé. É assim, em alguma medida, nos termos de Walter Benjamin, uma forma reveladora da desumanização. Surgia uma teatralidade a um tempo antiga e nova, que sinalizava o brutal mundo moderno que se produzia na colônia.

\section{Referências bibliográficas}

ALBUQUERQUE, L. de. Alguns documentos sobre a colonização do Brasil: século XVI. Lisboa: Alfa, 1989. p. 129-137.

ALENCASTRO, L. F. O trato dos viventes: formação do Brasil no Atlântico Sul. São Paulo: Companhia das Letras, 2000.

ALMEIDA, G. Na Festa de S. Lourenço. São Paulo: Comissão do IV Centenário, 1954.

ANCHIETA, J. Cartas: correspondência ativa e passiva. Pesquisa, introdução e notas: Pe. Hélio Abranches Viotti. São Paulo: Loyola, 1984.

Cartas: informações, fragmentos históricos e sermões. Belo Horizonte/ São Paulo: Itatiaia/Edusp, 1988.

. Nóbrega e outros. Rio de Janeiro: Serviço de Documentação do Ministério da Educação e Saúde, 1945.

Teatro de Anchieta. Tradução, introdução e notas: Pe. Armando Cardoso. São Paulo: Loyola, 1977. 
Teatro. Tradução do tupi: Eduardo de Almeida Navarro. Tradução do castelhano: Júlio César de Assunção Pedrosa. São Paulo: Martins Fontes, 1999.

AZPICUELTA NAVARRO; et al. Cartas avulsas, 1550-1568. Belo Horizonte/São

Paulo: Itatiaia/Edusp, 1988.

BELCHIOR, E. O. Conquistadores e povoadores do Rio de Janeiro. Rio de Janeiro: Livraria Brasiliana, 1965.

BENJAMIN, W. Origem do drama barroco alemão. São Paulo: Brasiliense, 1984.

BOSI, A. Dialética da colonização. 4. ed. São Paulo: Companhia das Letras, 1992.

CAFEZEIRO, E; GADELHA, C. História do Teatro Brasileiro: um percurso de Anchieta a Nélson Rodrigues. Rio de Janeiro: UFRJ, Eduerj, Funarte, 1996.

CARDIM, F. Tratados da terra e gente do Brasil. Belo Horizonte/São Paulo: Itatiaia/ Edusp, 1980.

CARVALHO, J. A. F. Os recebimentos de relíquias em S. Roque (Lisboa 1588) e em Santa Cruz (Coimbra 1595). Relíquias e espiritualidade. E alguma ideologia. Via spiritus, Porto, 8, 2001, p. 95-155. Disponível em: <http://ler.letras.up.pt/uploads/ ficheiros/3494.pdf>. Acesso em: 25 jun. 2015.

CAXA, Q; RODRIGUES, P. Primeiras biografias de José de Anchieta. Introdução e notas de Hélio Viotti. São Paulo: Loyola, 1988.

FEBVRE, L. História. Org. Carlos Guilherme Mota. São Paulo: Ática, 1978.

FRAPPIER, J; GOSSART, A. M. Le Théatre religieux au moyen âge: extraits de pièces. Paris: Librairie Larousse, 1935.

GANDAVO, P. M. Tratado da terra do Brasil e história da província de Santa Cruz. Belo Horizonte: Itatiaia; São Paulo: Edusp, 1980.

HESSEL, L.; RAEDERS, G. Teatro jesuítico. Porto Alegre: UFRGS, 1972.

LEITE, S. História da Companhia de Jesus no Brasil. tomo II. Lisboa/Rio de Janeiro: Portugália/Civilização Brasileira, 1938.

(Ed.) Monumenta Brasiliae II: 1553-1558. Roma: Monumenta Historica Societatis lesu, 1957.

(Ed.) Monumenta Brasiliae III: 1558-1563. Roma: Monumenta Historica Societatis lesu, 1958.

(Ed.) Monumenta Brasiliae IV: 1563-1568. Roma: Monumenta Historica Societatis lesu, 1960.

LEBÈGUE, R. Le diable dans I'ancien theatre religieux. Cahiers de l'Association internationale dês etudes françaises. Paris, n. 3-5, 1953, p. 97-105.

LÉRY, J. Viagem à terra do Brasil. Trad. Sérgio Milliet. Tradução do colóquio na língua brasílica: Plínio Ayrosa. Belo Horizonte/São Paulo: Itatiaia/Edusp, 1980.

MAGALDI, S. Panorama do teatro brasileiro. 3. ed. São Paulo: Global, 1997.

METRAUX, A. A religião dos tupinambás e suas relações com a das demais tribos tupi-guaranis. 2. ed. São Paulo: Editora Nacional; Edusp, 1979. 
NÓBREGA, M. Cartas do Brasil, 1549-1560. Belo Horizonte/São Paulo: Itatiaia/ Edusp, 1988.

. Cartas do Brasil e mais escritos. Introdução e notas: Serafim Leite. Belo Horizonte: Itatiaia, 2000.

. Diálogo sobre a conversão do gentio. Lisboa: Comissão do IV Cententário da Fundação de São Paulo, 1954.

PAULA MARTINS, M. de. L. de. Auto representado na festa de São Lourenço. São Paulo: Museu Paulista, 1948.

PÉREZ PRIEGO, M. A. Teatro medieval. Madri: Cátedra, 2009.

PONTES, J. Teatro de Anchieta. Rio de Janeiro: MEC, Serviço Nacional de Teatro, 1978.

PRADO, D. A. História concisa do teatro brasileiro: 1570-1908. São Paulo: Edusp, 1999.

Teatro de Anchieta a Alencar. São Paulo: Perspectiva, 1993.

ROUX, L. E. Le Theatre dans les collèges des jésuites en Espagne. In: ROUX, L.

E. Dramaturgie et societè: colloques international du centre national de la recherche scientifique. Études réunies et présentées: Jean Jacquot. tomo I. Paris: Editions du CNRS, 1968.

SARRAZAC, J. P. Critique du theatre: de l'utopie au désenchantement. Paris: Circe, 2000.

SERRÃO, J. V. O Rio de Janeiro no século XVI. 2. ed. Rio de Janeiro: Andrea Jakobsson Estúdio, 2008.

SOUSA, G. S. Tratado descritivo do Brasil em 1587. 4. ed. São Paulo: Companhia Editora Nacional; Edusp, 1971.

SOUSA, J. G. O teatro no Brasil. tomo I. Rio de Janeiro: Ministério da Educação e Cultura, 1960.

THEVET, A. As singularidades da França Antártica. Belo Horizonte/São Paulo: Itatiaia/Edusp, 1978.

VASCONCELOS, S. Crônica da Companhia de Jesus. 3. ed. Petrópolis/Brasília: Vozes/Instituto Nacional do Livro, 1977.

VICENTE DO SALVADOR, F. V. História do Brasil: 1500-1627. 6. ed. São Paulo/Brasília: Melhoramentos/INL, 1975.

VIOTTI, H. A. José de Anchieta. São Paulo: Tenenge; Raízes, 1987.

Recebido em 22/04/2015

Aprovado em 23/05/2015

Publicado em 30/06/2015 